\title{
Studies on Dibenzylamines as Inhibitors of Venezuelan Equine Encephalitis Virus
}

\author{
Theresa H. Nguyen, ${ }^{\dagger, \|}$ Nicole N. Haese, ${ }^{\ddagger}, \|$ Nikhil Madadi, ${ }^{\dagger}$ Sanjay Sarkar, ${ }^{\S}$ Kiley Bonin, ${ }^{\dagger}$
} Cassilyn E. Streblow, ${ }^{\ddagger}$ Sharon Taft-Benz, ${ }^{\S}$ Nichole A. Tower, ${ }^{\nabla}$ Lynn Rasmussen, ${ }^{\nabla}$ Robert Bostwick, ${ }^{\nabla}$ Corinne E. Augelli-Szafran, ${ }^{\dagger}$ Mark J. Suto, ${ }^{\dagger}$ Thomas E. Morrison, ${ }^{\perp}$ Victor DeFilippis, ${ }^{\ddagger}$ Mark T. Heise, ${ }^{\S}$ Daniel N. Streblow, *, ${ }^{*}$ and Ashish K. Pathak*,†

\footnotetext{
${ }^{\dagger}$ Chemistry Department, Drug Discovery Division, Southern Research, 2000 Ninth Avenue South, Birmingham, Alabama 35205, United States

${ }^{*}$ Vaccine and Gene Therapy Institute, Oregon Health \& Science University, 505 NW 185th Avenue, Beaverton, Oregon 97006, United States

${ }^{\S}$ Department of Genetics, University of North Carolina School of Medicine, Chapel Hill, North Carolina 27599, United States

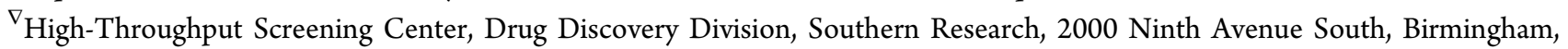
Alabama 35205, United States

${ }^{\perp}$ Department of Immunology and Microbiology, University of Colorado School of Medicine, 12800 E. 19th Avenue, Aurora, Colorado 80045, United States
}

\begin{abstract}
Alphaviruses are arthropod-transmitted members of the Togaviridae family that can cause severe disease in humans, including debilitating arthralgia and severe neurological complications. Currently, there are no approved vaccines or antiviral therapies directed against the alphaviruses, and care is limited to treating disease symptoms. A phenotypic cell-based high-throughput screen was performed to identify small molecules that inhibit the replication of Venezuelan Equine Encephalitis Virus (VEEV). The compound, 1-(2,3-dihydrobenzo[b][1,4]dioxin-6-yl)-N-(3-fluoro4-methoxybenzyl)ethan-1-amine (1), was identified as a
\end{abstract}
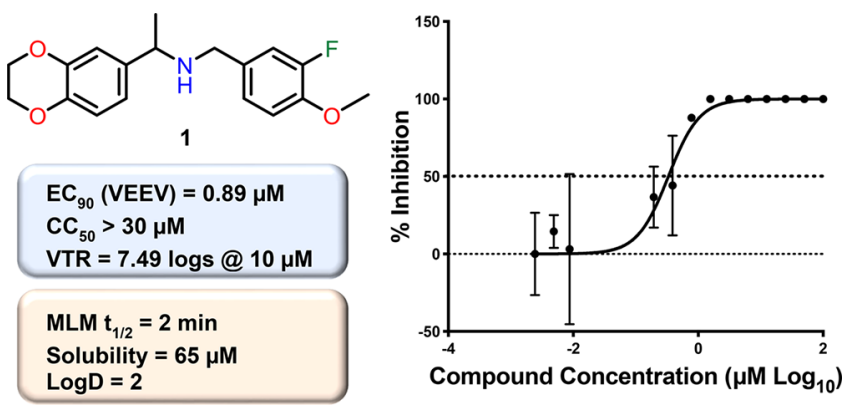
highly active, potent inhibitor of VEEV with an effective concentration for $90 \%$ inhibition of virus $\left(\mathrm{EC}_{90}\right)$ of $0.89 \mu \mathrm{M}$ and $7.49 \log$ reduction in virus titers at $10 \mu \mathrm{M}$ concentration. These data suggest that further investigation of compound 1 as an antiviral therapeutic against VEEV, and perhaps other alphaviruses, is warranted. Experiments suggested that the antiviral activity of compound $\mathbf{1}$ is directed at an early step in the VEEV replication cycle by blocking viral RNA and protein synthesis.

KEYWORDS: alphaviruses, VEEV, dibenzyl amines, antiviral inhibitors

\begin{abstract}
$\mathrm{A}$ lphaviruses, members of the Togaviridae family, are arthropod-borne pathogens responsible for a number of human and animal diseases. ${ }^{1}$ These positive-sense singlestranded RNA viruses are naturally transmitted by infected mosquitoes to horses, humans, birds, rodents, and other animals. The New World encephalitic alphaviruses, which include Venezuelan, Eastern, and Western Equine Encephalitis Viruses (VEEV, EEEV, and WEEV), cause acute viral infections in both human and equine populations, mainly targeting the central nervous system. ${ }^{2}$ Infection of humans commonly produces flu-like symptoms, which include sudden onset of fever, chills, severe headache, sore throat, nausea, and muscle pain that may progress to fatal encephalitis. ${ }^{3}$ A small percentage of VEEV infected humans (14\%) experience neurological symptoms, which occur more frequently in children than adults, ${ }^{4}$ and the mortality rate of VEEV is $<1 \% .^{5-7}$ In addition to the natural threat to human health, the encephalitic alphaviruses can be aerosolized and weaponized;
\end{abstract}

thus, they could be used as bioterrorism agents. Because of this, these viruses are classified as category B priority biodefense agents by the National Institute of Allergy and Infectious Diseases (NIAID) at NIH. ${ }^{8}$

Alphaviruses enter cells through receptor-mediated endocytosis and subsequently release the viral genome into the cytoplasm. ${ }^{9,10}$ The nonstructural proteins nsP123 and nsP1234 are synthesized first and then quickly form the replication complex in invaginations at the plasma membrane. ${ }^{11}$ Virus minus strand synthesis is driven by a complex containing nsP123 after nsP4 is released by proteolytic cleavage. The full length genomic and subgenomic RNA species are synthesized by fully cleaved nsP1234. ${ }^{12}$ The subgenomic RNA (sgmRNA)

Special Issue: Central Nervous System-Related Pathogens

Received: January 28, 2019

Published: June 29, 2019 
is translated into a single polyprotein that is cleaved by both host and viral proteases into mature structural proteins: capsid, E3, E2, 6k/TF, and E1. While several advances in the development of preventative or therapeutic treatments for VEEV infection have occurred over the past several years, ${ }^{13}$ there are currently still no Food and Drug Administration (FDA) licensed vaccines or therapeutic agents against VEEV or other alphaviruses available for human treatment. Thus, a critical need exists for the development of a safe and effective antiviral therapy for these encephalitic viral pathogens. ${ }^{14-17}$ Here, an approach of developing an efficient small molecule anti-VEEV compound as a new therapeutic is described.

\section{RESULTS AND DISCUSSION}

A collaborative drug discovery project was initiated under the Antiviral Drug Discovery and Development Center (1U19AI109680; http://www.uab.edu/medicine/ad3c/) to identify novel small molecules with antiviral activity against VEEV. A high-throughput screening (HTS) campaign was designed and conducted on the basis of a previously developed screen (PubChem: AID 588723). ${ }^{18,19}$ A VeroE6 cell-based assay was used to measure the capacity of 197025 unique compounds to block VEEV-induced cytopathic effects (CPE) at a single concentration. From this screen, 940 compounds were identified to actively inhibit VEEV-induced CPE by $>12 \%$. These 940 compounds were then tested in a 10-point dose-response CPE assay to determine 50\% effective concentration $\left(\mathrm{EC}_{50}\right)$ values as well as in a 10-point doseresponse cell viability assay to determine $50 \%$ cytotoxicity concentration $\left(\mathrm{CC}_{50}\right)$, both performed in the same cell line used in the HTS. These compounds were further evaluated for both antiviral activity and cytotoxicity in telomerized human foreskin fibroblasts (THFFs) to determine $\mathrm{EC}_{50}$ and $\mathrm{CC}_{50}$ values. Antiviral data from both cell lines showed strong agreement on the activity of these compounds, and 17 compounds were selected for further antiviral activity on the basis of $\mathrm{EC}_{50}(<10 \mu \mathrm{M})$ and $\mathrm{CC}_{50}(>40 \mu \mathrm{M})$ values after Pan Assay Interference Compounds (PAINS) ${ }^{20}$ filtration and visual inspection for any undesirable structural alerts. These 17 compounds were then repurchased for reconfirmation in the antiviral assay; their purity (high-performance liquid chromatography, HPLC) and integrity (high resolution electrospray ionization mass spectra, HR-ESIMS, and ${ }^{1} \mathrm{H}$ NMR) were evaluated, and then, they were subsequently tested in a virus titer reduction (VTR) assay. The dibenzyl amine compound 1 (Figure 1) showed potent antiviral inhibition with $90 \%$ effective concentration $\left(\mathrm{EC}_{90}=0.89 \mu \mathrm{M}\right)$ and $7.49 \log$ of VTR at $10 \mu \mathrm{M}$ concentration with no cytotoxicity up to $30 \mu \mathrm{M}$ concentration using THFF cells. Hence, this hit compound was selected for lead optimization. In addition, compound $\mathbf{1}$

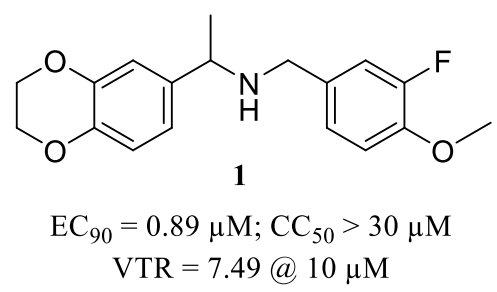

Figure 1. Structure, antiviral activity, and cellular cytotoxicity of compound 1. also underwent mode-of-action mechanistic studies against VEEV to aid lead generation and optimization studies.

Hit-to-Lead Chemistry. The design and synthesis of novel inhibitors of VEEV were the focus for identifying potent, noncytotoxic analogs of compound $\mathbf{1}$ with desirable drug-like properties, including solubility $(\geq 10 \mu \mathrm{M}), \log \mathrm{D}(2-4)$, and microsomal stability (human liver microsomes (HLM) and mouse liver microsomes $(\mathrm{MLM})=t_{1 / 2} \geq 60$ and $\geq 30 \mathrm{~min}$, respectively). Due to the efficacious (VTR $\geq 3 \mathrm{log}$ ), potent $\left(\mathrm{EC}_{90} \leq 1 \mu \mathrm{M}\right)$, and noncytotoxic $\left(\mathrm{CC}_{50} \geq 30 \mu \mathrm{M}\right)$ properties of compound 1, solubility (in $\mathrm{pH} 7.4$ buffer) and microsomal stability [human (HLM) and mouse (MLM)] analyses were conducted to define starting in vitro physiochemical and absorption, distribution, metabolism, and excretion (ADME) parameters of this hit compound. Compound 1 showed acceptable solubility of $65 \mu \mathrm{M}$ with poor half-life $\left(t_{1 / 2}\right)$ in human (HLM) and mouse (MLM) liver microsomes of 8 and 2 min, respectively. In addition, StarDrop calculations were implemented using cytochrome $\mathrm{P} 450$ metabolism predictions to calculate the composite site liability (CSL) and identify metabolically unstable areas in compound 1 . The calculated CSL values are used as a measure of the metabolism efficiency of a molecule by seven of the major drug metabolizing isoforms of CYP. Figure 2 highlights the most prominent labile

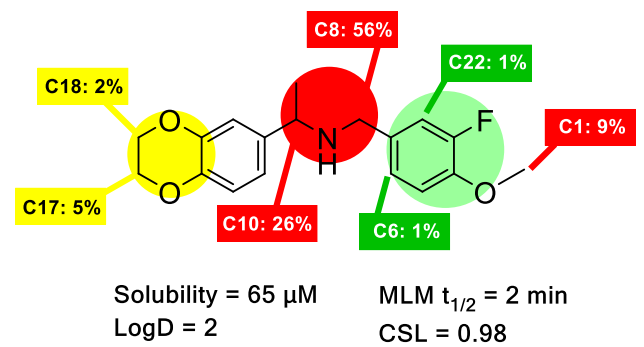

Figure 2. StarDrop predictions for composite site liability, experimental solubility, and $\log \mathrm{D}$ of compound 1. Composite site liability (CSL) is a measure of metabolism efficiency of a compound by an isoform (e.g., CYP3A4). CSL values are between 0 and 1 , with the lower values indicating greater metabolic stability by a CYP isoform . Red $=$ very labile, yellow $=$ moderately labile, and green $=$ slightly labile.

sites of compound $\mathbf{1}$ as the two benzylic positions and the methoxy group (labeled in red). The methylenes of the dioxane moiety labeled in yellow were predicted to be moderately labile. The structure-activity relationship (SAR) studies involved three areas of compound 1, which are indicated in Figure 2 as yellow, red, and green. Modifications to these areas would be to improve microsomal stability while retaining the antiviral activity and potency.

We first wanted to determine the requirement of the 1,4dioxane ring located in the left-hand portion of the compound. Analogs 4 and 5 (Table 1, entries 2 and 3) were designed to determine whether removal or ring opening of the dioxane moiety was tolerated. The synthesis of these dibenzyl amine analogs 4 and 5 was accomplished in moderate yields via a substitution reaction of the appropriate benzyl amine $\mathbf{2}$ and benzyl bromide 3 in the presence of $\mathrm{K}_{2} \mathrm{CO}_{3}$ with conventional heating (Scheme 1, eq 1). Analogs 4 and 5 were tested for antiviral activity against VEEV in a VTR assay using normal human dermal fibroblast (NHDF) cells at $10 \mu \mathrm{M}$ concentration. Neither of these 2 analogs showed $>2 \log$ for VTR, which suggests that a bicyclic ring system may be required for 
Table 1. Antiviral Evaluation of Analogs against VEEV and in Vitro ADME Data ${ }^{a}$

\begin{tabular}{|c|c|c|c|c|c|c|c|c|}
\hline Entry & ID & $\mathbf{R}^{1}$ & $\begin{array}{c}\text { VTR (logs) } \\
\text { at } 10 \mu \mathrm{M}\end{array}$ & $\begin{array}{l}\mathbf{E C}_{90} \\
(\mu \mathrm{M})\end{array}$ & $\begin{array}{l}\mathrm{CC}_{50} \\
(\mu \mathrm{M})\end{array}$ & $\begin{array}{c}\text { Solubility } \\
(\mu \mathrm{M})\end{array}$ & $\log D$ & $\begin{array}{l}\text { MLM } \\
t_{1 / 2}(\min )\end{array}$ \\
\hline 1 & 1 & & 7.49 & 0.89 & 29.6 & 65 & 2.2 & 2 \\
\hline 2 & 4 & & 0.87 & $\mathrm{ND}$ & $>30$ & ND & $\mathrm{ND}$ & ND \\
\hline 3 & 5 & & 1.4 & ND & $>30$ & ND & ND & ND \\
\hline 4 & 6 & & 3.2 & 1.2 & $>30$ & 19 & 3.4 & 3 \\
\hline 5 & 10 & & 7.7 & 2.5 & $>30$ & 68 & 2.8 & $<1$ \\
\hline 6 & 11 & & 7.7 & 2.3 & $>30$ & 75 & 1.8 & 4 \\
\hline 7 & 14 & & 6.1 & 3.1 & $>30$ & 68 & 2.1 & 3 \\
\hline 8 & 15 & & $<1$ & $>10$ & $>30$ & ND & ND & ND \\
\hline 9 & 16 & & $<1$ & $>10$ & $>30$ & ND & $\mathrm{ND}$ & ND \\
\hline 10 & 17 & & $<1$ & $>10$ & $>30$ & ND & ND & $\mathrm{ND}$ \\
\hline 11 & 18 & & 1.3 & $>10$ & $>30$ & ND & ND & ND \\
\hline 12 & 39 & & 9.1 & 0.38 & 15 & 48 & 2.6 & $<1$ \\
\hline 13 & 40 & & 4.9 & 0.37 & $>30$ & 21 & 4.2 & $<1$ \\
\hline
\end{tabular}

${ }^{a} \mathrm{VTR}=$ virus titer reduction; $\mathrm{EC}_{90}=$ antiviral inhibition with $90 \%$ effective concentration; $\mathrm{CC}_{50}=50 \%$ cytotoxicity concentration; $\mathrm{MLM} t_{1 / 2}=$ half-life in mouse liver microsomes.

Scheme 1. General Routes to Dibenzyl Amine Derivatives ${ }^{a}$<smiles>[R]C(C)N</smiles>

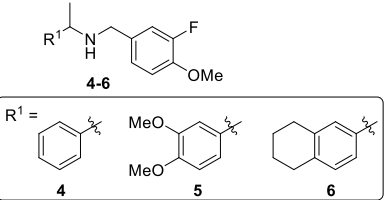

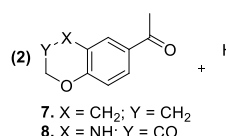
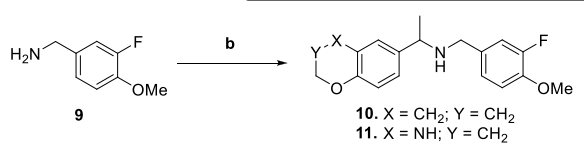

(3)

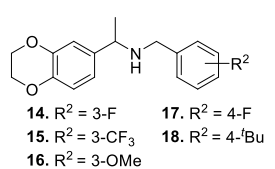

${ }^{a}$ Reagents and conditions: (a) $\mathrm{K}_{2} \mathrm{CO}_{3}, \mathrm{DMF}, 50-80{ }^{\circ} \mathrm{C}, 16 \mathrm{~h}, 11-$ $79 \%$; (b) para-toluenesulfonic acid ( $p$-TSA), toluene, reflux, 12-16 h, then $\mathrm{NaBH}_{3} \mathrm{CN}$ or lithium aluminum hydride (LAH), overnight, then $\mathrm{H}_{2}, \mathrm{Pd} / \mathrm{C}, \mathrm{MeOH}, 26-87 \%$. antiviral activity. Hence, $\mathrm{EC}_{90}$ 's were not determined (Table 1, entries 2 and 3). The scope of the bicyclic ring system of compound 1 was examined by evaluating various rings, such as fused cyclohexyl-, pyran-, and morpholino-phenyl rings, compounds 6, 10, and $\mathbf{1 1}$, respectively (Scheme 1). Compound $\mathbf{6}$ was prepared in a similar fashion as compound 4 (Scheme 1, eq 1), while compounds 10 and 11 were prepared via reductive amination of the desired ketone 7 or 8 with 3-fluoro-4-methoxybenzylamine (9), respectively (Scheme 1, eq 2). Compound 6 showed an efficacy of 3.2 $\log$ at $10 \mu \mathrm{M}$ in the VTR assay and possessed $\mathrm{EC}_{90}$ of $1.2 \mu \mathrm{M}$, which is very comparable to compound 1 . However, no improvement was seen in microsomal stability versus compound 1 (MLM $t_{1 / 2}=3 \mathrm{~min}$ ) (Table 1, entry 4). Although analogs 10 and 11 showed very high VTR ( 7.7 log at $10 \mu \mathrm{M}$ ), the $\mathrm{EC}_{90}$ increased 3 -fold versus compound $\mathbf{1}$, and there was no significant improvement in MLM values (Table 1, entries 5 and 6). As these minor modifications failed to improve both the antiviral activity and microsomal stability, our SAR efforts shifted to examining the right-hand portion of compound 1. 
Thus, analogs centered on preserving the left-hand dioxane phenyl moiety while replacing the right benzyl group with monosubstituted benzyl derivatives were evaluated. Compounds 14-18 (Table 1, entries 7-11) were synthesized in a single step nucleophilic substitution from benzyl amine 12 and the appropriate benzyl halides in low-to-moderate yields (Scheme 1, eq 3). Elimination of the 4-methoxy group to afford the meta-fluoro benzyl analog 14 provided a VTR of 6.1 $\log$ at $10 \mu \mathrm{M}$. However, potency was reduced by 3 -fold $\left(\mathrm{EC}_{90}\right.$ of $3.1 \mu \mathrm{M}$; Table 1, entry 7). Replacing the meta-fluoro substituent on the phenyl ring with electron-withdrawing or electron-donating substituents, such as $\mathrm{CF}_{3}$ (15) and $\mathrm{OMe}$ (16), was not well-tolerated, and antiviral potency decreased by 11 -fold (Table 1, entries 8 and 9). Likewise, migrating the fluoro-substituent from the meta- to the para-position in compound 17 and the $p$-t-butylbenzyl substitution in compound 18 also resulted in a loss of antiviral activity by 11-fold (Table 1, entries 10 and 11).

Since modifying the left-and right-hand rings of compound 1 afforded no improvement in anti-VEEV activity or in microsomal stability, the middle ring of compound $\mathbf{1}$ was then explored. Since the benzylic positions of compound 1 were indicated by the StarDrop P450 calculations (Figure 2) to be labile sites, compounds 19-24 were designed to address this. The scope for cyclizing the left- and right-hand benzylic moieties included tetraisoquinoline 19 and indole derivatives 20 and 21 (Figure 3). Likewise, cyclizing the two benzylic

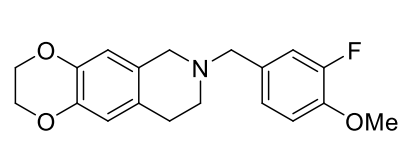

19

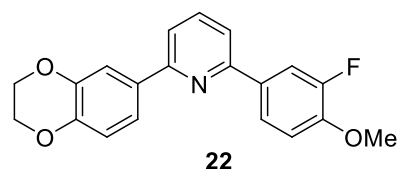

22

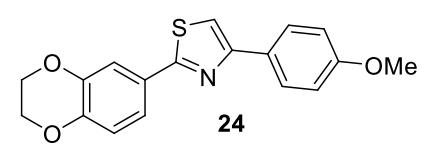

Figure 3. Scope of heterocyclic-containing analogs to stabilize the benzylic moiety.

moieties into nitrogen containing rings afforded analogs such as pyridine $\mathbf{2 2}$, piperidine $\mathbf{2 3}$, and thiazole $\mathbf{2 4}$ (Figure 3 ). Initial VTR studies on analogs 19-24 showed no antiviral activity $(<1 \log )$ at $10 \mu \mathrm{M}$ concentration.

The observed loss of potency with cyclizing any of the three structural components in the middle portion of the molecule guided our attention toward investigating analogs with modification of the benzylic functionality. The presence of the benzyl components was highlighted in analogs 28,29 , and 30 by removal of both benzyl positions or select removal of the right benzyl or left benzyl position, respectively. These analogs were readily synthesized via a Buchwald-Hartwig amination of the corresponding amine and aryl halide (Scheme 2, eq 1). Condensing the center amine linker via elimination of one or both benzyl components resulted in no antiviral potency (VTR $\leq 1 \log$ at $10 \mu \mathrm{M}$ concentration), thus emphasizing the importance of retaining the benzylic functionality toward antiviral activity.

We studied an alternative strategy of blocking the right benzyl moiety with various substitutions including analogs that possess a sulfonyl (33), carbonyl (34), and cyclopropyl (37) group in order to increase metabolic stability pertaining to the benzyl moiety. Synthesis of sulfonamide 33 was completed via a substitution of benzyl amine $\mathbf{1 2}$ and sulfonyl chloride 31 in the presence of triethylamine in $50 \%$ yield (Scheme 2 , eq 2 ). Incorporating a carbonyl to give amide 34 was achieved via a 1-[bis(dimethylamino)methylene]-1H-1,2,3-triazolo[4,5-b]pyridinium 3-oxide hexafluorophosphate(HATU) mediated coupling of amine $\mathbf{1 2}$ and carboxylic acid 32 (Scheme 2, eq 2 ), while dibenzyl amine 37 , bearing a cyclopropyl, was prepared via reductive amination of ketone 35 and cyclopropylamine 36 (Scheme 2, eq 3 ). Lack of potency (VTR $\leq 1$ $\log$ at $10 \mu \mathrm{M}$ concentration) and poor microsomal stability (MLM $t_{1 / 2}<1 \mathrm{~min}$ ) were observed in all three analogs. Since we were unable to resolve the issue of microsomal stability by modifying the predicted labile sites calculated in StarDrop, we investigated the potential metabolites of compound $\mathbf{1}$ using high resolution mass spectroscopy. The major metabolite was identified as a hydroxy analog in which a hydroxyl group is inserted at the left benzyl position; thus, a methyl group was incorporated in the left benzyl position to stabilize the molecule. The gem-dimethyl analog 39 was prepared by converting methyl ketone $\mathbf{3 1}$ to tertiary amine $\mathbf{3 8}$ over three steps (39\% yield) followed by a substitution reaction with the desired 3-fluoro-4-methoxybenzyl bromide in 56\% yield (Scheme 2, eq 4). Compound 39 showed excellent antiviral efficacy $(\mathrm{VTR}=9.1 \log$ at $10 \mu \mathrm{M})$ and improved potency by 2 fold $\left(\mathrm{EC}_{90}=0.38 \mu \mathrm{M}\right)$ against VEEV; however, increased cytotoxicity $\left(\mathrm{CC}_{50}=15 \mu \mathrm{M}\right)$ and poor metabolic stability were noted (Table 1, entry 12). A similar gem-dimethyl analog 40, prepared similarly described for compound 39 , in which the right benzyl moiety was removed, exhibited high antiviral potency $\left(\mathrm{EC}_{90}=0.37 \mu \mathrm{M}\right)$ and efficacy $(\mathrm{VTR}=4.9 \mathrm{log}$ at 10 $\mu \mathrm{M})$ with no toxicity observed up to a $30 \mu \mathrm{M}$ concentration (Table 1, entry 13). However, analog $\mathbf{4 0}$ displayed poor microsomal stability (MLM $t_{1 / 2}<1 \mathrm{~min}$ ), further indicating that insertion of the gem-dimethyl moiety on the left benzylic group and complete removal of the right benzyl moiety did not improve microsomal stability.

Antiviral Breadth and Mechanism of Action. To assess the antiviral breadth of compound 1, we compared the antiviral activity in cells from two different relevant species: humans (NHDF) and mosquitos (Aedes albopictus C6/36). A 10-point dose response assay was performed with compound concentrations ranging from 100 to $0.19 \mu \mathrm{M}$. Compound 1 was added to NHDF cells and C6/36 cells $1 \mathrm{~h}$ prior to infection with $\mathrm{VEEV}_{\mathrm{TC} 83}$ with a multiplicity of infection (MOI) of 1 (Figure 4). At $2 \mathrm{~h}$ postinfection (hpi), cells were washed and fresh medium was added containing compound 1 . Culture supernatants were collected at $24 \mathrm{hpi}$, and infectious virus was quantified by standard plaque assays. Compound 1 reduced viral titers to background levels at $6.25 \mu \mathrm{M}$ in human fibroblasts and maximally reduced virus titers by $>2 \log$ in C6/36 cells with $\mathrm{CC}_{50}>40 \mu \mathrm{M}$ (Figure 4), indicating compound activity in both cell types. Next, we evaluated the antiviral breadth of compound 1 by treating NHDF cells with dimethyl sulfoxide (DMSO) or compound 1 at 1 or $10 \mu \mathrm{M} 1 \mathrm{~h}$ prior to infection with other human alphaviruses including Chikungunya virus $(\mathrm{CHIKV})$ at $\mathrm{MOI}=1$, O'nyong nyong 
Scheme 2. Synthetic Route of Analogs with Modification of the Benzyl Functionality ${ }^{a}$

(1)<smiles>[R]c1ccc2c(c1)OCCO2</smiles>

25. $\mathrm{R}^{1}=\mathrm{NH}_{2}$ 12. $\mathrm{R}^{1}=\mathrm{CH}(\mathrm{Me}) \mathrm{NH}_{2}$ 26. $\mathrm{R}^{1}=\mathrm{Br}$

(2)<smiles>CC(N)c1ccc2c(c1)OCCO2</smiles>

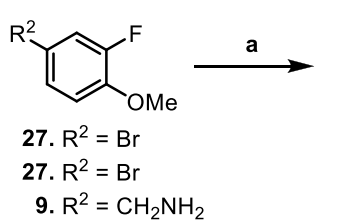<smiles>[R]c1ccc(OC)c(F)c1</smiles>

31. $\mathrm{R}^{2}=\mathrm{SO}_{2} \mathrm{Cl}$ 32. $\mathrm{R}^{2}=\mathrm{CO}_{2} \mathrm{H}$<smiles>COc1ccc(C2(N)CC2)cc1F</smiles>

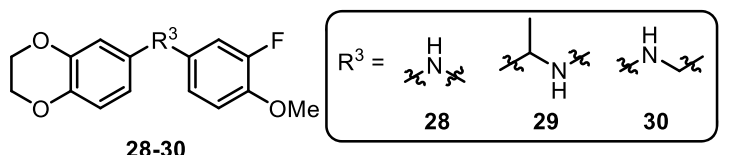

28-30<smiles>COc1ccc([X]NC(C)c2ccc3c(c2)OCCO3)cc1F</smiles>

33. $\mathrm{X}=\mathrm{SO}_{2}$

34. $\mathrm{X}=\mathrm{CO}$

(3)<smiles>CC(=O)c1ccc2c(c1)OCCO2</smiles>

35<smiles>COc1ccc(C(C)(C)NC(C)c2ccc3c(c2)OCCO3)cc1F</smiles>

37

(4)

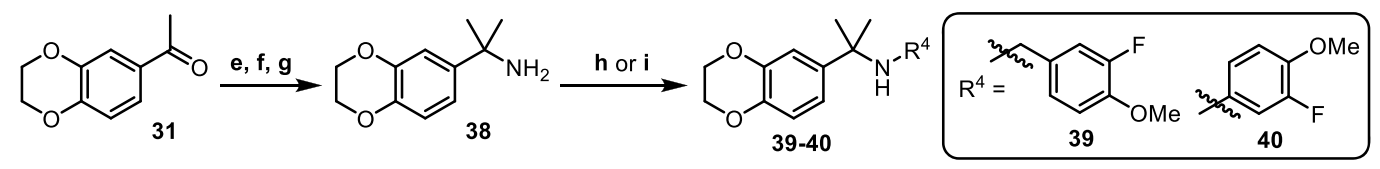

${ }^{a}$ Reagents and conditions: (a) $\mathrm{Pd}_{2} \mathrm{dba}_{3}$, BrettPhos, $\mathrm{K}-\mathrm{O}^{t} \mathrm{Bu}$, toluene, $80^{\circ} \mathrm{C}, 16 \mathrm{~h}, 34-82 \%$; (b) TEA, DCM, $3 \mathrm{~h}, 50 \%$; (c) HATU, DIPEA, DMF, $16 \mathrm{~h}, 19 \%$; (d) p-TSA, toluene reflux, $12 \mathrm{~h}$, then $\mathrm{NaBH}_{4}, 16 \mathrm{~h}, 12 \%$; (e) $\mathrm{MeMgBr} / \mathrm{THF},-78{ }^{\circ} \mathrm{C}, 16 \mathrm{~h}, 85 \%$; (f) $\mathrm{NaN}, \mathrm{TFA}, \mathrm{DCM}, 12 \mathrm{~h}, 49 \%$; (g) $\mathrm{H}_{2} \mathrm{Pd} / \mathrm{C}, \mathrm{MeOH}$, overnight, 94\%; (h) 3-fluoro-4-methoxybenzyl bromide, $\mathrm{K}_{2} \mathrm{CO}_{3}$, DMF, $80{ }^{\circ} \mathrm{C}, 12 \mathrm{~h}, 56 \%$; (i) 27, $\mathrm{Pd}_{2} \mathrm{dba}_{3}, \mathrm{BrettPhos}^{\circ} \mathrm{K}-\mathrm{O}^{t} \mathrm{Bu}$, toluene, $80{ }^{\circ} \mathrm{C}, 16 \mathrm{~h}, 34 \%$.
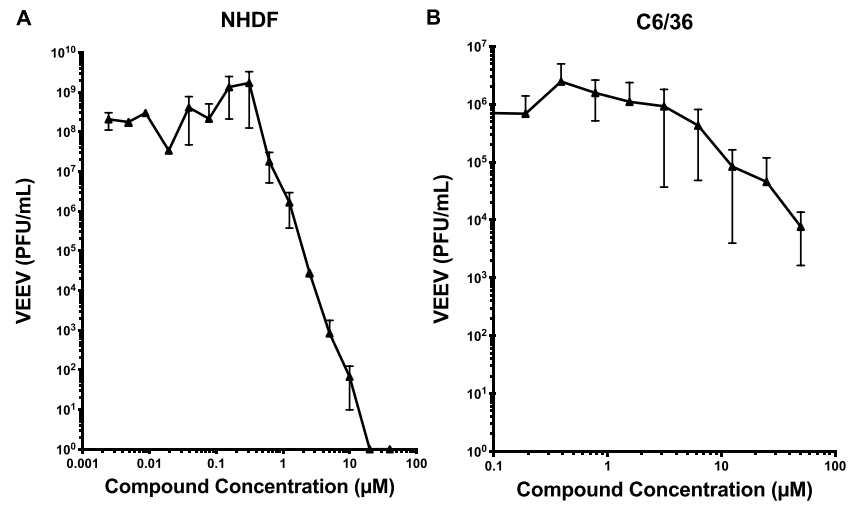

Figure 4. Antiviral activity of compound 1 in (A) NHDF cells and (B) Aedes albopictus C6/36 cells. Cells were pretreated for $1 \mathrm{~h}$ with DMSO or 2-fold serial dilutions of compound 1 ranging from 100 to $0.2 \mu \mathrm{M}$. Treated cells were infected with $\mathrm{VEEV}_{\mathrm{TC} 83}$ at an MOI of 1 in the presence of compound. At $2 \mathrm{hpi}$, the culture media was removed and the cells were washed once with PBS. Medium containing compound was replenished, and supernatants were collected $24 \mathrm{hpi}$; infectious virus was quantified by the plaque assay on Vero cells. The data is graphed as the mean, and error bars represent the standard deviation. $\mathrm{IC}_{90}$ values were calculated using Prism software and is representative of three independent experiments.

virus $(\mathrm{ONNV})$ at $\mathrm{MOI}=2$, Ross River virus $(\mathrm{RRV})$ at $\mathrm{MOI}=$ 2, Una virus (UNAV) at MOI $=2$, and Mayaro virus (MAYV) at $\mathrm{MOI}=2$. At $2 \mathrm{hpi}$, cells were washed and fresh medium with compound 1 was added. Supernatants from the infected cells were collected at $24 \mathrm{hpi}$ for infectious virus quantification by plaque assays. Compound $\mathbf{1}$ failed to elicit any significant inhibitory effect against CHIKV, ONNV, RRV, UNAV, and MAYV (Figure 5).

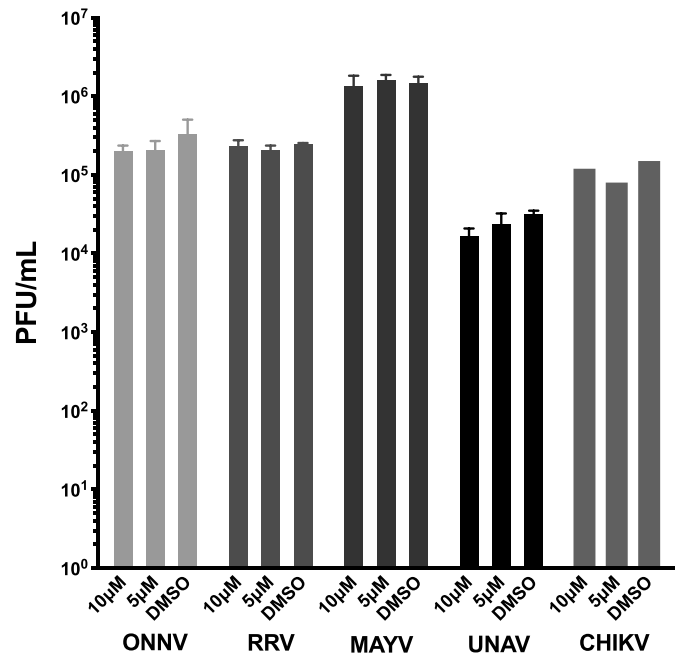

Figure 5. Breadth of antiviral activity of compound 1 . NHDF cells were pretreated for $1 \mathrm{~h}$ with DMSO or compound 1 at 10 or $1 \mu \mathrm{M}$. Treated cells were then infected with $\mathrm{CHIKV}_{181-25}, \mathrm{MAYV}_{\text {TRVL }}$ ONNV, RRV, or UNAV $\mathrm{UAC150}_{\text {in }}$ in the presence of compound. At 2 hpi, culture medium was removed; cells were washed once with PBS, and medium containing compound was added. Supernatants were collected $24 \mathrm{hpi}$, and infectious virus was quantified by the plaque assay on Vero cells after $48 \mathrm{~h}$ of incubation $(n=3)$. Mean titers and standard deviation are graphed. The data is representative of two independent experiments.

To determine the step(s) in the VEEV life cycle that are affected by compound $\mathbf{1}$ treatment, a time of compound addition experiment was performed. In this assay, production of infectious virus was quantified in supernatants from NHDF cells infected with VEEV $(\mathrm{MOI}=1)$ treated with compound $\mathbf{1}$, the inactive analog (compound 5), or DMSO at $0,2,4,6,8$, 
and 10 hpi. Treatment of CHIKV infected cells was included as a control. Compound $\mathbf{1}$ reduced VEEV production by nearly 3 log when added at all time points (0-10 hpi) (Figure 6). Treatment of infected cells with compound 5 or DMSO failed to affect VEEV infectious virus production. CHIKV was unaffected by compounds $\mathbf{1}$ and $\mathbf{5}$.

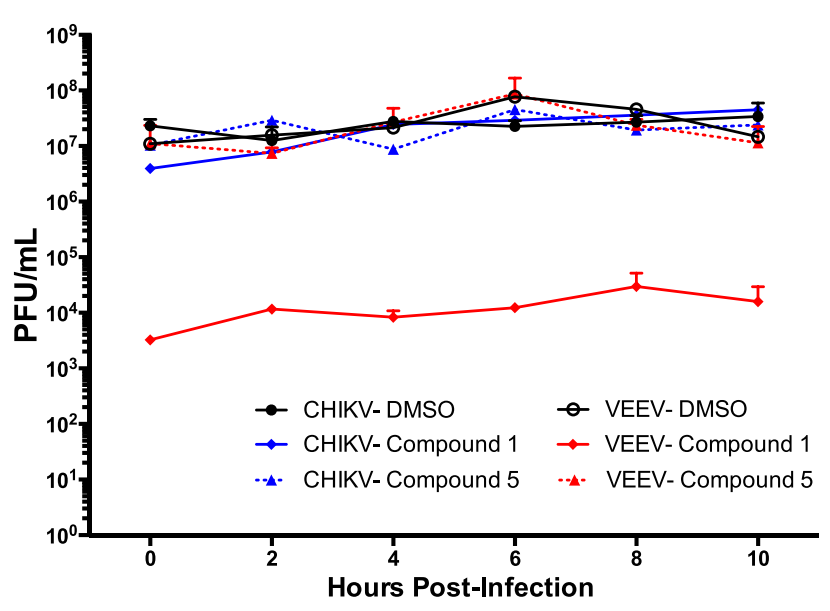

Figure 6. Compound 1 time of drug addition assay. NHDF cells were infected with $\mathrm{VEEV}_{\mathrm{TC} 83}$ or $\mathrm{CHIKV}_{181-25}$ at an MOI $=1$ and treated with DMSO, $10 \mu \mathrm{M}$ compound 1 , or $10 \mu \mathrm{M}$ compound 5 at $0,2,4,6$, 8 , and $10 \mathrm{hpi}$. Supernatants were collected at $24 \mathrm{hpi}$, and infectious virus was quantified by the plaque assay on Vero cells $(n=3)$. Mean and standard deviation (error bars) are graphed. The data is representative of two independent experiments.

To further define the stage where compound 1 blocks VEEV replication, a VEEV replicon particle (VRP) based on a vaccine strain of the Trinidad donkey strain of VEEV (VEE 3526) was used as described previously. ${ }^{21}$ These VRPs consists of VEE 3526 replicon RNA encoding the replicase proteins and a $26 \mathrm{~S}$ promoter from which GFP is expressed. VRPs can undergo only one round of replication and cannot form progeny VRPs from the infected cells. Therefore, if compound 1 blocks GFP expression, this would indicate that the drug acts on the viral lifecycle prior to viral 26S RNA translation. Human embryonic kidney 293T cells (HEK-293T) were pretreated with either compound 1 or $3(1,5$, and $10 \mu \mathrm{M})$ or DMSO for $1 \mathrm{~h}$ and then infected with VRP at an MOI of $1 \mathrm{PFU} /$ cell. At $8 \mathrm{hpi}$, cells were washed and fixed with $4 \%$ paraformaldehyde and analyzed by flow cytometry. Compound 1 reduces the percentage of GFP-expressing cells compared to DMSOtreated cells (Figure 7A). Consistent with prior results, the inactive compound $\mathbf{5}$ had no effect on replicon gene expression. These results indicate that compound $\mathbf{1}$ inhibits translation of the $26 \mathrm{~S}$ subgenomic RNA or a step prior to this event. Next, we bypassed the entry step of the VRPs by transfecting HEK-293T cells with replicon RNA in the presence of DMSO or compound 1 or 5 . At 24 hpi, cells were washed, fixed, and analyzed by flow cytometry for the expression of GFP. Compound 1 significantly reduced the number of VRP-GFP positive HEK-293T cells compared to DMSO or compound $\mathbf{5}$ (Figure $7 \mathrm{~B}$ ). In addition, compound 1 treatment caused a marked reduction of mean fluorescence intensity (MFI) of the VRP-GFP positive cells, indicating that compound 1 treatment inhibited expression of VRP genes (Figure 7C). Therefore, bypassing entry does not rescue viral gene expression in the presence of compound 1, which indicates that the compound inhibits VEEV replication at a postentry step.

To further identify the step in viral replication affected by compound 1, we examined VEEV RNA and protein production in cells treated with the compound. Northern blotting analysis was used to determine the effect of the compound on accumulation of the 49s (genomic) and 26s (subgenomic) VEEV RNA species at $12 \mathrm{hpi}$. NHDF cells were pretreated with DMSO or $10 \mu \mathrm{M}$ of compound 1 or 5 for $1 \mathrm{~h}$ prior to infection with $\operatorname{VEEV}_{\mathrm{TC} 83}(\mathrm{MOI}=5)$. At $2 \mathrm{hpi}$, cells were washed and fresh media containing compound was added to the cells. Total RNA was isolated from the cells using TRIzol reagent at $12 \mathrm{hpi}$, separated on a $1 \%$ formaldehyde agarose gel, and transferred to an $\mathrm{N}^{+}$membrane by capillary transfer. The membrane was hybridized with a DIG-labeled RNA probe specific for a $1 \mathrm{~kb}$ fragment of the VEEV RNA segment present in both the 26 s and 49 s RNA species as well as a loading control probe directed against a $1 \mathrm{~kb}$ fragment of human $\beta$-actin. Probe binding was visualized after staining with an anti-DIG antibody followed by incubation with a CSPD alkaline phosphatase substrate. Compound $\mathbf{1}$ treatment abolished the accumulation of both 49s and 26s VEEV RNA species in comparison to control DMSO-treated and compound 5 -treated cells, indicating compound 1 blocks viral RNA synthesis (Figure 8). As expected, due to the block in viral RNA synthesis, compound $\mathbf{1}$ also inhibited VEEV structural protein expression (capsid and glycoprotein) as is evident from the Western blotting analysis of the cell lysates
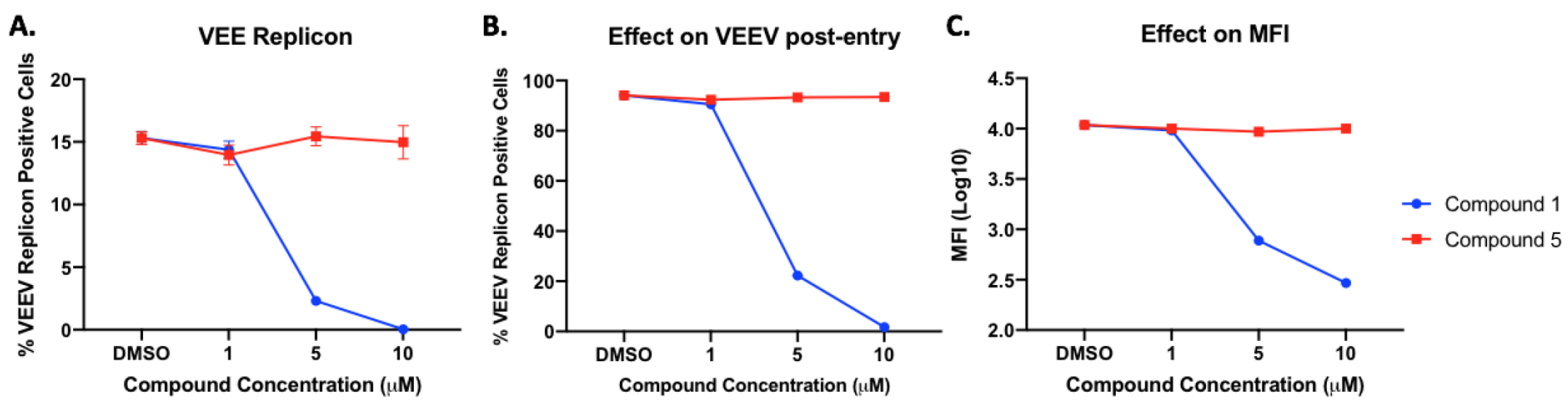

Figure 7. Effect of compound $\mathbf{1}$ on VEEV entry. (A) HEK-293T cells were pretreated with compound $\mathbf{1}$ at 1,5 , or $10 \mu \mathrm{M}$, compound $\mathbf{5}$ at $10 \mu \mathrm{M}$, or DMSO for $1 \mathrm{~h}$ and then infected with VRP-GFP at an MOI of 1 . At $8 \mathrm{hpi}$, cells were washed and fixed with $4 \%$ PFA and analyzed by flow cytometry. (B, C) HEK-293T cells were pretreated with compounds as in (A) and transfected with in vitro transcribed VRP RNA. At 24 hpt, cells were fixed in $4 \%$ PFA and analyzed by flow cytometry. The figure represents the mean with the standard deviation from one of three independent experiments performed in triplicate. 


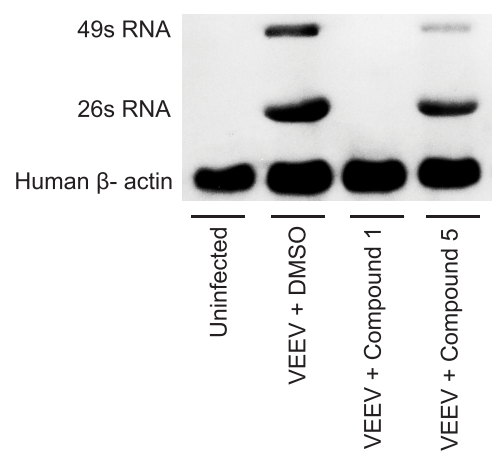

Figure 8. Compound 1 treatment inhibits $\operatorname{VEEV}_{\mathrm{TC} 83} 49 \mathrm{~s}$ and $26 \mathrm{~s}$ RNA accumulation. NHDF cells were pretreated for $1 \mathrm{~h}$ with DMSO, $10 \mu \mathrm{M}$ compound $\mathbf{1}$, or $10 \mu \mathrm{M}$ compound $\mathbf{5}$. Treated cells were then infected with $\mathrm{VEEV}_{\mathrm{TC} 83}$ at an MOI of 5 in the presence of compound. At $2 \mathrm{hpi}$, cells were washed with PBS and medium containing compounds was added. Cell lysates collected at $12 \mathrm{hpi}$ in trizol; RNA was isolated and analyzed by Northern blot for 49 s and 26s VEEV RNA levels using VEEV specific DIG labeled probes and the control human $\beta$-actin probe $(n=3$, best representative image). Representative image of three technical replicates.

prepared from the VEEV infected Vero cells at $12 \mathrm{hpi}$ (Figure $9 \mathrm{~A}-\mathrm{C})$. An immunofluorescence assay was performed on the Vero cells infected with $\mathrm{VEEV}_{\mathrm{TC}-83}$ in the presence of compound 1, which also showed inhibition of VEEV glycoprotein expression (Figure 9D). In both WB and IFA, compound $\mathbf{5}$ and DMSO treatment did not block VEEV protein synthesis.

To further confirm the effect of compound 1 on viral gene expression, we generated two $\mathrm{VEEV}_{\mathrm{TC} 83}$ reporter viruses expressing NanoLuc (nLuc; 513 nt; Promega) as a fusion with either nsP3 (TC83 nsP3-nLuc) or between capsid and PE2 (TC83-Cap-nLuc) using approaches similar to those described by Sun et al. ${ }^{22}$ These reporter viruses allow us to monitor expression of both the viral nonstructural proteins and structural proteins. Vero cells were pretreated with DMSO or compound 1 or 5 for $1 \mathrm{~h}$ before being infecting with TC83
nsP3-nLuc or TC83-Cap-nLuc viruses (MOI = 5). At $12 \mathrm{hpi}$, cells were washed twice with cold PBS and lysed using the Nano-Glo Luciferase Assay system (Promega). Consistent with the replicon and Western blot results (Figures 7 and 9), compound 1 blocked expression of the capsid NanoLuc fusion TC83-Cap-nLuc (Figure 10A). Furthermore, compound 1
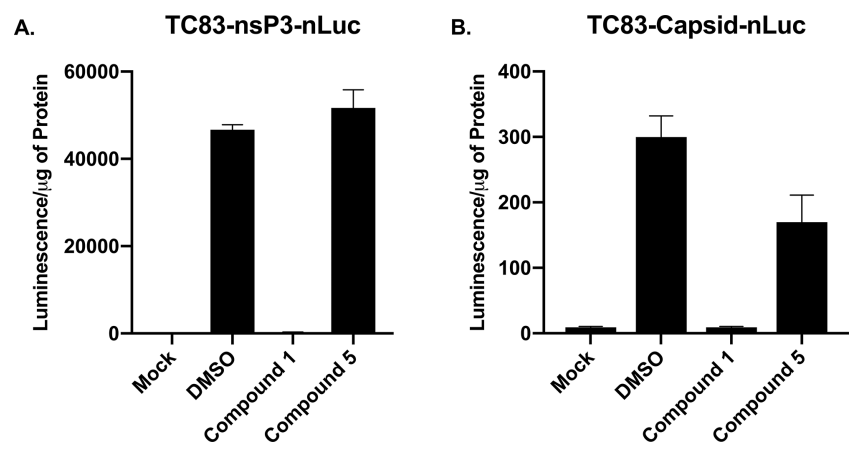

Figure 10. Compound 1 inhibits protein synthesis of nonstructural and structural genes fused inframe with nLuc. Vero cells were pretreated with compound $1(10 \mu \mathrm{M})$, compound $5(10 \mu \mathrm{M})$, or DMSO for $1 \mathrm{~h}$ prior to infection with recombinant VEEV expressing nLuc (A) TC83 nsP3-nLuc and (B) TC83-Cap-nLuc at MOI $=5$. Cells were washed with PBS at $2 \mathrm{hpi}$, and medium containing compounds was added. At $12 \mathrm{hpi}$, cells were lysed and Nano-Glo luciferase assays were performed. The figure represents the mean with the standard deviation from one of three independent experiments performed in triplicate.

treatment markedly reduced luminescence in TC83 nsP3-nLuc virus infected cells compared to DMSO and compound 5 treated infected cells (Figure 10B). These results indicated that compound 1 acts either by blocking early viral RNA amplification or by blocking viral nonstructural protein translation.
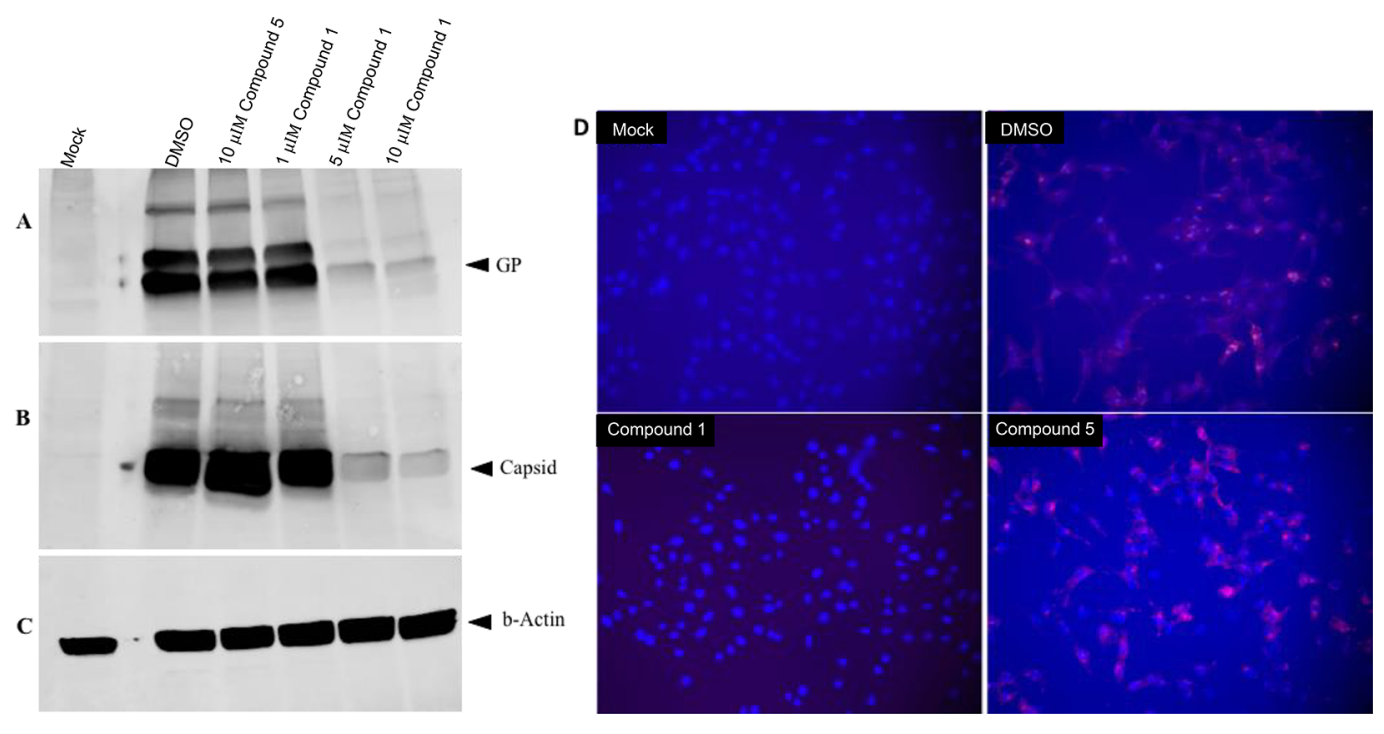

Figure 9. Effect of compound $\mathbf{1}$ on VEEV protein synthesis. Vero cells were pretreated with compound $\mathbf{1}(1,5$, and $10 \mu \mathrm{M})$, compound $\mathbf{5}$ (10 $\mu \mathrm{M})$, or DMSO for $1 \mathrm{~h}$ before infection with $\mathrm{VEEV}_{\mathrm{TC}-83}$ at an $\mathrm{MOI}=5$. At $2 \mathrm{hpi}$, cells were washed and medium containing compounds was added. At $12 \mathrm{hpi}$, cells were either lyzed for Western blot analysis with (A) anti-VEEV GP, (B) anti-VEEV capsid, and (C) control $\beta$-actin antibodies or (D) fixed for indirect immunofluorescence assay using anti-VEEV GP antibody. The figure is representative of three independent experiments. 


\section{CONCLUSIONS}

Currently, there are no FDA licensed vaccines or therapeutics targeting the encephalitic alphaviruses for use in humans. Since members of this virus family are in circulation and have the potential for outbreaks that would cause devastating neurological outcomes, there is a great need for the development of antivirals directed against alphaviruses. Herein, we have designed and synthesized analogs of compound $\mathbf{1}$ as potential VEEV replication inhibitors. SAR studies were completed, which evaluated three areas of compound 1. In pursuit of the lead optimization of hit compound 1, a few selected analogs showed an improved activity profile, including low cytotoxicity and high potency and efficacy. However, the challenge of addressing microsomal stability in these analogs was unresolved. Ultimately, compound $\mathbf{4 0}$ showed an increase in potency by 2 -fold in comparison to compound $1\left(\mathrm{EC}_{90}=0.37\right.$ $\mu \mathrm{M}, \mathrm{VTR}=4.9 \log$ at $10 \mu \mathrm{M})$ with no cytotoxicity $\left(\mathrm{CC}_{50}>30\right.$ $\mu \mathrm{M}$ ). However, poor microsomal stability was observed (MLM $<1 \mathrm{~min})$. Target identification and mechanism of action studies were also conducted. Compound 1 blocked virus replication at an early step in the virus lifecycle postbinding and entry. The compound blocked viral RNA and protein accumulation indicative of a block in nonstructural protein function. However, generation of a resistant virus to compound 1 was unsuccessful, which might indicate that compound 1 targets an essential viral component or a host function critical for virus replication. Continued studies to address the challenging issue of metabolic stability while retaining potency and efficacy and to determine the specific mechanism of action for compound $\mathbf{1}$ are ongoing.

\section{EXPERIMENTAL SECTION}

General Chemistry. The reactions were performed under a dry argon atmosphere, and reaction temperatures were measured externally. Anhydrous solvents over molecular sieves were purchased from Aldrich and used as such in reactions. Microwave (MW) reactions were performed in the CEM Discover Labmate System with Intelligent Technology for Focused Microwave Synthesizer (Explorer 48). The reactions were monitored by thin-layer chromatography (TLC) on precoated silica gel $\left(60 \mathrm{~F}_{254}\right)$ aluminum plates $(0.25 \mathrm{~mm})$ from E. Merck and visualized using UV light $(254 \mathrm{~nm})$. Purification of the compounds was performed on an Isco Teledyne Combiflash Rf200. Universal RediSep solid sample loading prepacked cartridges ( $5.0 \mathrm{~g}$ silica) were used to absorb crude product and purified on $12 \mathrm{~g}$ silica RediSep Rf Gold Silica (20-40 $\mu \mathrm{m}$ spherical silica) columns using appropriate solvent gradients. Pure samples were dried overnight under high vacuum before analyses. The high resolution electrospray ionization mass spectral data (HR-ESIMS) were obtained on an Agilent LC-MSTOF. ${ }^{1} \mathrm{H}$ NMR spectra were recorded at $400 \mathrm{MHz}$ on an Agilent/Varian MR-400 spectrometer with $\mathrm{CDCl}_{3}, \mathrm{CD}_{3} \mathrm{OD}$, or DMSO- $d_{6}$ as solvents. The chemical shifts $(\delta)$ are in ppm downfield from standard tetramethylsilane (TMS). HPLC analyses of the final compounds were run on an Agilent 1100 LC equipped with a diode array UV detector and were monitored at 254 and $280 \mathrm{~nm}$ using the following methods: Method A = Kinetix $5 \mu \mathrm{C} 18,150 \times 4.6 \mathrm{~mm}$ column using Solvent A, $0.1 \%$ trifluoroacetic acid (TFA) in $\mathrm{H}_{2} \mathrm{O}$; Solvent B, $0.1 \%$ TFA in $\mathrm{MeCN}$; flow rate, $1.0 \mathrm{~mL} / \mathrm{min} ; 20 \mathrm{~min}$ linear gradient from $5 \%$ to $95 \% \mathrm{~B}$; hold for $2 \mathrm{~min}$ and then back to $95 \%$ A over $3 \mathrm{~min}$. Method B = SunFire C18 $5 \mu \mathrm{m}, 4.6$ $\times 150 \mathrm{~mm}$ column using Solvent A, 0.1\% TFA in $\mathrm{H}_{2} \mathrm{O}$; Solvent $\mathrm{B}, 0.1 \% \mathrm{TFA}$ in $\mathrm{MeCN}$; flow rate, $2.0 \mathrm{~mL} / \mathrm{min} ; 15 \mathrm{~min}$ linear gradient from $10 \%$ to $90 \% \mathrm{~B}$ and then back to $10 \% \mathrm{~B}$ over 0.1 min and held for $4.9 \mathrm{~min}$. Method $\mathrm{C}=$ Kinetix $5 \mu \mathrm{C} 18,150 \times$ $4.6 \mathrm{~mm}$ column using Solvent $\mathrm{A}, \mathrm{H}_{2} \mathrm{O}$; Solvent $\mathrm{B}, \mathrm{MeCN}$; flow rate, $1.0 \mathrm{~mL} / \mathrm{min}, 15 \mathrm{~min}$ linear gradient from $10 \%$ to $90 \% \mathrm{~B}$ and then held for $5 \mathrm{~min}$. Method $\mathrm{D}=$ Kinetix $5 \mu \mathrm{C} 18,150 \times$ $4.6 \mathrm{~mm}$ column using Solvent $\mathrm{A}, \mathrm{H}_{2} \mathrm{O}$; Solvent $\mathrm{B}, \mathrm{MeCN}$; flow rate, $1.0 \mathrm{~mL} / \mathrm{min}$; $20 \mathrm{~min}$ linear gradient from $5 \%$ to $95 \% \mathrm{~B}$, hold for 2 min and then back to $95 \%$ A over 3 min. Method $\mathrm{E}$ $=$ Kinetix $5 \mu \mathrm{C} 18,150 \times 4.6 \mathrm{~mm}$ column using Solvent A, $0.1 \% \mathrm{HCO}_{2} \mathrm{H}$ in $\mathrm{H}_{2} \mathrm{O}$; Solvent $\mathrm{B}, 0.1 \% \mathrm{HCO}_{2} \mathrm{H}$ in $\mathrm{MeCN}$; flow rate, $1.0 \mathrm{~mL} / \mathrm{min} ; 20 \mathrm{~min}$ linear gradient from $0 \%$ to $90 \%$ B; hold for $2 \mathrm{~min}$ and then back to $100 \%$ A over $3 \mathrm{~min}$.

General Procedure 1 (GP1). A mixture of amine or amine$\mathrm{HCl}$ salt ( 1 equiv), benzyl bromide ( 1 equiv), and $\mathrm{K}_{2} \mathrm{CO}_{3}$ (12 equiv) in anhydrous dimethylformamide (DMF; $0.25 \mathrm{M}$ ) was heated overnight at $50-70{ }^{\circ} \mathrm{C}$. The reaction was cooled to room temperature, diluted with $\mathrm{H}_{2} \mathrm{O}(15 \mathrm{~mL})$, and extracted with EtOAc $(3 \times 10 \mathrm{~mL})$. Combined organic layers were washed with brine $(10 \mathrm{~mL})$, dried over anhydrous $\mathrm{Na}_{2} \mathrm{SO}_{4}$, filtered, and concentrated in vacuo.

General Procedure 2 (GP2). To an oven-dried, $25 \mathrm{~mL}$ round-bottom flask were added indole/benzimidazole (1 equiv) and sodium hydride (60\% dispersion in mineral oil; 1.1 equiv) under argon. The flask was evacuated and filled with argon three times followed by the addition of 6-(bromomethyl)-2,3-dihydrobenzo[b][1,4]dioxine (1.1 equiv) and DMF (2 $\mathrm{mL})$. After stirring overnight at room temperature, the reaction was quenched with saturated $\mathrm{NH}_{4} \mathrm{Cl}$ and extracted with dichloromethane (DCM; $3 \times 10 \mathrm{~mL})$. Combined organic layers were dried over anhydrous $\mathrm{Na}_{2} \mathrm{SO}_{4}$, filtered, and concentrated under vacuum.

General Procedure 3 (GP3). To a $25 \mathrm{~mL}$ Schlenk flask with a stir bar were added $\mathrm{Pd}_{2}(\mathrm{dba})_{3}(1 \mathrm{~mol} \%)$, BrettPhos $(3 \mathrm{~mol}$ $\%)$, and $\mathrm{KO}^{\mathrm{t}} \mathrm{Bu}(1.5-2.5$ equiv). The flask was evacuated and filled with argon three times, followed by addition of amine (1.3 equiv), aryl bromide ( 1 equiv), and anhydrous toluene $(0.3 \mathrm{M})$. The flask was sealed, heated at $80^{\circ} \mathrm{C}$, and stirred overnight. Upon completion, the reaction was diluted with EtOAc, filtered through a short pad of silica gel, and concentrated in vacuo.

General Procedure 4 (GP4). Using a Dean-Stark apparatus, ketone ( 1 equiv), benzyl amine (1 equiv), and $p$ toluenesulfonic acid monohydrate ( 0.1 equiv) were refluxed in anhydrous toluene or tetrahydrofuran (THF; $0.2 \mathrm{M}$ ) for $12-16 \mathrm{~h}$. After imine formation, confirmed via mass spectra, the reaction was concentrated in vacuo and dried under high vacuum. The appropriate reducing agent was then used in the subsequent step as described below.

1-(2,3-Dihydrobenzo[b][1,4]dioxin-6-yl)-N-(3-fluoro-4methoxybenzyl)ethan-1-amine (1). 1 was purchased from Enamine (Z139650624). ${ }^{1} \mathrm{H}$ NMR (400 MHz, DMSO- $\left.d_{6}\right) \delta$ $7.35(\mathrm{~d}, J=12.3 \mathrm{~Hz}, 1 \mathrm{H}), 7.20(\mathrm{dd}, J=4.5,1.3 \mathrm{~Hz}, 2 \mathrm{H}), 7.08$ (s, 1H), $6.97(\mathrm{~d}, J=8.7 \mathrm{~Hz}, 1 \mathrm{H}), 6.92(\mathrm{~d}, J=8.3 \mathrm{~Hz}, 1 \mathrm{H})$, $4.26(\mathrm{~s}, 4 \mathrm{H}), 4.24(\mathrm{~s}, 1 \mathrm{H}), 3.98(\mathrm{~s}, 1 \mathrm{H}), 3.85(\mathrm{~s}, 3 \mathrm{H}), 3.77(\mathrm{~s}$, $1 \mathrm{H}), 1.54(\mathrm{~d}, 3 \mathrm{H})$. HR-ESIMS $(\mathrm{m} / z)$ : calcd for $\mathrm{C}_{18} \mathrm{H}_{21} \mathrm{FNO}_{3}$ $(\mathrm{M}+\mathrm{H})^{+} 318.15$; found 318.1497 . HPLC purity $=98 \%$ (Method A; retention time $\left(t_{\mathrm{R}}\right)=9.65 \mathrm{~min}$ ).

$\mathrm{N}$-(3-Fluoro-4-methoxybenzyl)-1-phenylethan-1-amine (4). Following GP1 with 4-(bromomethyl)-2-fluoro-1-methoxybenzene $(110 \mathrm{mg}, 0.5 \mathrm{mmol})$ and 1-phenylethanamine (64 $\mu \mathrm{L}, 0.5 \mathrm{mmol})$, the resulted product was purified via flash 
chromatography (0-15\% EtOAc/hexanes) to give the desired compound 4 (102 mg, 79\%) as a light-yellow oil. ${ }^{1} \mathrm{H}$ NMR $\left(400 \mathrm{MHz}, \mathrm{CD}_{3} \mathrm{OD}\right) \delta 7.37-7.29(\mathrm{~m}, 4 \mathrm{H}), 7.25$ (dddt, $J=$ 8.4, 5.6, 3.2, $1.6 \mathrm{~Hz}, 1 \mathrm{H}), 7.06-6.91(\mathrm{~m}, 3 \mathrm{H}), 3.84(\mathrm{~d}, J=0.9$ $\mathrm{Hz}, 3 \mathrm{H}), 3.76-3.68(\mathrm{~m}, 1 \mathrm{H}), 3.47(\mathrm{q}, J=13.1 \mathrm{~Hz}, 2 \mathrm{H}), 1.35$ $(\mathrm{dd}, J=6.7,1.0 \mathrm{~Hz}, 3 \mathrm{H}) .{ }^{13} \mathrm{C} \mathrm{NMR}\left(100 \mathrm{MHz}, \mathrm{CD}_{3} \mathrm{OD}\right) \delta$ $154.75,152.31,147.98,145.71,133.90,133.85,129.60,128.21$, 127.91, 125.47, 125.44, 117.06, 116.88, 114.50, 58.36, 56.71, 56.67, 51.21, 51.19, 23.85. HR-ESIMS $(\mathrm{m} / z)$ : calcd for $\mathrm{C}_{16} \mathrm{H}_{19} \mathrm{FNO}(\mathrm{M}+\mathrm{H})^{+}$260.1445; found 260.1443. HPLC purity $=100 \%$ (Method B; $\left.t_{\mathrm{R}}=3.91 \mathrm{~min}\right)$.

1-(3,4-Dimethoxyphenyl)-N-(3-fluoro-4-methoxybenzyl)ethan-1-amine (5). Following GP1 with 4-(bromomethyl)-2fluoro-1-methoxybenzene $(110 \mathrm{mg}, 0.5 \mathrm{mmol})$ and 1-(3,4dimethoxyphenyl)ethanamine hydrochloride (109 mg, 0.5 $\mathrm{mmol}$ ), the resulted product was purified via flash chromatography (0-33\% EtOAc/hexanes) to give the desired compound 5 (100 mg, 63\%) as a yellow oil. ${ }^{1} \mathrm{H}$ NMR (400 MHz, $\left.\mathrm{CD}_{3} \mathrm{OD}\right) \delta 7.08-6.93(\mathrm{~m}, 4 \mathrm{H}), 6.91(\mathrm{~d}, J=8.2 \mathrm{~Hz}, 1 \mathrm{H}), 6.83$ (dt, $J=8.4,1.4 \mathrm{~Hz}, 1 \mathrm{H}), 3.83(\mathrm{dd}, J=2.3,1.0 \mathrm{~Hz}, 6 \mathrm{H}), 3.82$ $(\mathrm{d}, J=0.9 \mathrm{~Hz}, 3 \mathrm{H}), 3.68(\mathrm{q}, J=6.7 \mathrm{~Hz}, 1 \mathrm{H}), 3.48(\mathrm{q}, J=13.2$ $\mathrm{Hz}, 2 \mathrm{H}), 1.34(\mathrm{dd}, J=6.7,1.0 \mathrm{~Hz}, 3 \mathrm{H}) .{ }^{13} \mathrm{C}$ NMR $(100 \mathrm{MHz}$, $\left.\mathrm{CD}_{3} \mathrm{OD}\right) \delta 154.71,152.28,150.67,149.56,148.03,138.64$, $134.04,133.99,125.48,120.54,117.08,117.07,116.89,114.50$, 112.91, 111.44, 58.08, 56.71, 56.67, 56.51, 56.47, 56.41, 56.37, 51.20, 23.90. HR-ESIMS $(\mathrm{m} / z)$ : calcd for $\mathrm{C}_{18} \mathrm{H}_{23} \mathrm{FNO}_{3}(\mathrm{M}+$ $\mathrm{H})^{+}$320.1656; found 320.1645. HPLC purity $=98 \%$ (Method B; $\left.t_{\mathrm{R}}=3.78 \mathrm{~min}\right)$.

N-(3-Fluoro-4-methoxybenzyl)-1-(5,6,7,8-tetrahydronaphthalen-2-yl)ethan-1-amine (6). Following GP1 with 4(bromomethyl)-2-fluoro-1-methoxybenzene (110 mg, 0.5 mmol) and 1-(5,6,7,8-tetrahydronaphthalen-2-yl)ethanamine ( $87 \mu \mathrm{L}, 0.5 \mathrm{mmol}$ ), the resulted product was purified via flash chromatography $(0-15 \% \mathrm{EtOAc} /$ hexanes $)$ to give the desired compound $6(91 \mathrm{mg}, 58 \%)$ as a yellow oil. ${ }^{1} \mathrm{H}$ NMR (400 $\left.\mathrm{MHz}, \mathrm{CD}_{3} \mathrm{OD}\right) \delta 7.05-6.87(\mathrm{~m}, 6 \mathrm{H}), 3.83(\mathrm{~s}, 3 \mathrm{H}), 3.63(\mathrm{q}, J$ $=6.6 \mathrm{~Hz}, 1 \mathrm{H}), 3.54-3.38(\mathrm{~m}, 2 \mathrm{H}), 2.74(\mathrm{q}, J=5.5 \mathrm{~Hz}, 4 \mathrm{H})$, $1.79(\mathrm{~m}, J=4.3 \mathrm{~Hz}, 4 \mathrm{H}), 1.32(\mathrm{~d}, J=6.6 \mathrm{~Hz}, 3 \mathrm{H}) .{ }^{13} \mathrm{C} \mathrm{NMR}$ $\left(100 \mathrm{MHz}, \mathrm{CD}_{3} \mathrm{OD}\right) \delta 154.77,152.34,148.07,142.68,138.14$, 136.95, 134.09, 134.03, 130.25, 128.55, 125.48, 125.45, 125.03, $117.11,116.93,114.50,58.14,56.74,56.69,51.21,30.48$, 30.11, 24.49, 23.80. HR-ESIMS $(\mathrm{m} / z)$ : calcd for $\mathrm{C}_{20} \mathrm{H}_{25} \mathrm{FNO}$ $(\mathrm{M}+\mathrm{H})^{+}$314.1915; found 314.1911. HPLC purity $=100 \%$ (Method B; $\left.t_{\mathrm{R}}=5.99 \mathrm{~min}\right)$.

1-(Chroman-6-yl)-N-(3-fluoro-4-methoxybenzyl)ethan-1amine (10). GP4 was followed with 1-(chroman-6-yl)ethanone 7 (70 mg, $0.4 \mathrm{mmol})$, (3-fluoro-4-methoxyphenyl)methanamine ( $55 \mu \mathrm{L}, 0.4 \mathrm{mmol}) 9$, and $p$-toluenesulfonic acid monohydrate $(7.6 \mathrm{mg}, 0.04 \mathrm{mmol})$. To the resulted imine in dichloroethane $(1 \mathrm{~mL})$ were added acetic acid $(0.4 \mathrm{~mL}, 6.99$ $\mathrm{mmol}$ ) and sodium cyanoborohydride $(71 \mathrm{mg}, 1.1 \mathrm{mmol})$ at 0 ${ }^{\circ} \mathrm{C}$ under argon, and the mixture was stirred overnight. Upon completion, monitored via TLC, the reaction was quenched with saturated $\mathrm{NaHCO}_{3}(3 \mathrm{~mL})$ and then extracted with EtOAc $(3 \times 5 \mathrm{~mL})$. The combined organic layer was dried over anhydrous $\mathrm{Na}_{2} \mathrm{SO}_{4}$, filtered, and concentrated in vacuo. The product was purified via flash chromatography (0-9\% $\mathrm{MeOH} / \mathrm{DCM})$ to give the desired compound $10(62 \mathrm{mg}$, $87 \%)$ as a clear sticky oil. ${ }^{1} \mathrm{H}$ NMR $\left(400 \mathrm{MHz}, \mathrm{CDCl}_{3}\right) \delta$ 7.14-6.93 (m, 5H), $6.84(\mathrm{~d}, J=8.4 \mathrm{~Hz}, 1 \mathrm{H}), 4.25-4.17(\mathrm{~m}$, $2 \mathrm{H}), 4.09(\mathrm{q}, J=6.8 \mathrm{~Hz}, 1 \mathrm{H}), 3.92-3.83(\mathrm{~m}, 4 \mathrm{H}), 3.77(\mathrm{~d}, J=$ $13.3 \mathrm{~Hz}, 1 \mathrm{H}), 2.82(\mathrm{t}, J=6.4 \mathrm{~Hz}, 2 \mathrm{H}), 2.08-2.03(\mathrm{~m}, 2 \mathrm{H})$, $1.67(\mathrm{~d}, J=6.8 \mathrm{~Hz}, 3 \mathrm{H}) .{ }^{13} \mathrm{C} \mathrm{NMR}\left(100 \mathrm{MHz}, \mathrm{CDCl}_{3}\right) \delta$
$155.99,153.24,150.77,148.53,129.14,126.81,126.53,126.38$ $123.56,117.69,117.61,117.42,113.80,66.68,58.42,56.26$, 48.82, 29.68, 24.85, 21.97, 20.22. HR-ESIMS $(\mathrm{m} / z)$ : calcd for $\mathrm{C}_{19} \mathrm{H}_{23} \mathrm{FNO}_{2}(\mathrm{M}+\mathrm{H})^{+} 316.1707$; found 316.1711. HPLC purity $=94 \%$ (Method $\left.A ; t_{\mathrm{R}}=10.43 \mathrm{~min}\right)$.

1-(3,4-Dihydro-2H-benzo[b][1,4]oxazin-6-yl)-N-(3-fluoro4-methoxybenzyl)ethan-1-amine (11). GP4 was followed with 6-acetyl-2H-benzo[b][1,4] oxazin-3(4H)-one (76 mg, 0.4 mmol) 8, (3-fluoro-4-methoxyphenyl)methanamine $9(55 \mu \mathrm{L}$, $0.4 \mathrm{mmol})$, and $p$-toluenesulfonic acid monohydrate $(7.6 \mathrm{mg}$, $0.04 \mathrm{mmol}$ ). The resulted amide intermediate was dissolved in anhydrous THF $(4 \mathrm{~mL})$ without purification followed by lithium aluminum hydride $(0.038 \mathrm{~g}, 1 \mathrm{mmol})$ addition under argon at $-78{ }^{\circ} \mathrm{C}$. The reaction mixture was warmed to room temperature with stirring and further refluxed overnight. The reaction mixture was cooled to $0{ }^{\circ} \mathrm{C}$ and quenched with water $(0.5 \mathrm{~mL})$ and then $10 \% \mathrm{NaOH}(0.5 \mathrm{~mL})$. The mixture was filtered through Celite, and the filtrate was concentrated in vacuo. The residue was extracted with DCM $(3 \times 5 \mathrm{~mL})$, dried over anhydrous $\mathrm{Na}_{2} \mathrm{SO}_{4}$, filtered, and concentrated in vacuo. To a hydrogenation bottle was added the crude imine intermediate in $\mathrm{MeOH}(2 \mathrm{~mL})$. Under an argon atmosphere, $10 \mathrm{~mol} \% \mathrm{Pd} / \mathrm{C}(21.3 \mathrm{mg}, 0.02 \mathrm{mmol})$ was quickly added to the hydrogenation bottle; it was then capped and placed on the hydrogenator. The reaction was run at 38 psi overnight; it was then filtered through Celite, rinsed well with $\mathrm{MeOH}$, and concentrated in vacuo. The product was purified via flash chromatography $(0-5 \% \mathrm{MeOH} / \mathrm{DCM}+0.3 \%$ triethylamine, TEA) to give the desired compound 11 (33 mg, 26\%) as a yellow oil. ${ }^{1} \mathrm{H}$ NMR $\left(400 \mathrm{MHz}, \mathrm{CDCl}_{3}\right) \delta 7.05$ (dd, $J=12.2$, $2.1 \mathrm{~Hz}, 1 \mathrm{H}), 6.99-6.94(\mathrm{~m}, 1 \mathrm{H}), 6.88(\mathrm{t}, J=8.4 \mathrm{~Hz}, 1 \mathrm{H}), 6.74$ $(\mathrm{d}, J=8.1 \mathrm{~Hz}, 1 \mathrm{H}), 6.63-6.57(\mathrm{~m}, 2 \mathrm{H}), 4.28-4.22(\mathrm{~m}, 2 \mathrm{H})$, $3.87(\mathrm{~s}, 3 \mathrm{H}), 3.64(\mathrm{q}, J=6.6 \mathrm{~Hz}, 1 \mathrm{H}), 3.61-3.49(\mathrm{~m}, 2 \mathrm{H})$, $3.45-3.40(\mathrm{~m}, 2 \mathrm{H}), 1.32(\mathrm{~d}, J=6.6 \mathrm{~Hz}, 3 \mathrm{H}) .{ }^{13} \mathrm{C} \mathrm{NMR}(100$ $\left.\mathrm{MHz}, \mathrm{CDCl}_{3}\right) \delta 153.50,151.06,146.46,146.35,143.11$, $138.04,133.54,123.75,123.71,117.18,116.53,116.02,115.84$, 113.56, 113.21, 113.19, 65.23, 56.91, 56.33, 56.32, 50.52, 41.01, 24.28. HR-ESIMS $(m / z)$ : calcd for $\mathrm{C}_{18} \mathrm{H}_{22} \mathrm{FN}_{2} \mathrm{O}_{2}(\mathrm{M}+$ $\mathrm{H})^{+}$317.1659; found 317.1661. HPLC purity $=95 \%$ (Method $\left.\mathrm{B} ; t_{\mathrm{R}}=4.04 \mathrm{~min}\right)$.

1 - (2,3-Dihydrobenzo[b][1,4]dioxin-6-yl)-N-(3fluorobenzyl)ethan-1-amine (14). Following GP1 with 1(2,3-dihydrobenzo[b][1,4] dioxin-6-yl)ethanamine (100 mg, $0.56 \mathrm{mmol}$ ) and 1-(bromomethyl)-3-fluorobenzene (105 mg, $0.56 \mathrm{mmol}$ ), the resulting product was purified via flash chromatography (0-15\% EtOAc/hexanes) to give the desired compound 14 (35 mg, 22\%). $\left.{ }^{1} \mathrm{H} \mathrm{NMR} \mathrm{(400} \mathrm{MHz,} \mathrm{CDCl}_{3}\right) \delta$ $7.29-7.22(\mathrm{~m}, 2 \mathrm{H}), 7.02-6.95(\mathrm{~m}, 2 \mathrm{H}), 6.88(\mathrm{~d}, J=1.9 \mathrm{~Hz}$, $1 \mathrm{H}), 6.86-6.79(\mathrm{~m}, 2 \mathrm{H}), 4.26(\mathrm{~s}, 4 \mathrm{H}), 3.69(\mathrm{q}, J=6.6 \mathrm{~Hz}$, $1 \mathrm{H}), 3.65-3.52(\mathrm{~m}, 2 \mathrm{H}), 1.34(\mathrm{~d}, J=6.6 \mathrm{~Hz}, 3 \mathrm{H}) .{ }^{13} \mathrm{C}$ NMR $\left(100 \mathrm{MHz}, \mathrm{CDCl}_{3}\right) \delta 163.26,160.82,143.63,142.68,138.11$, $135.59,130.07,129.99,119.78,117.33,115.53,115.33,115.12$, 77.16, 64.50, 64.44, 57.02, 50.65, 24.23. HR-ESIMS $(\mathrm{m} / z)$ : calcd for $\mathrm{C}_{17} \mathrm{H}_{19} \mathrm{FNO}_{2}(\mathrm{M}+\mathrm{H})^{+}$288.1394; found 288.1391. HPLC purity $=100 \%\left(\right.$ Method $\left.A ; t_{\mathrm{R}}=9.30 \mathrm{~min}\right)$.

1 - (2,3-Dihydrobenzo[b] [1,4]dioxin-6-yl)-N-(3(trifluoromethyl)benzyl)ethan-1-amine (15). Following GP1 with 1-(2,3-dihydrobenzo[b][1,4]dioxin-6-yl)ethanamine (100 $\mathrm{mg}, 0.56 \mathrm{mmol}$ ) and 1-(bromomethyl)-3-(trifluoromethyl)benzene $(133 \mathrm{mg}, 0.56 \mathrm{mmol})$, the resulting product was purified via flash chromatography (0-15\% EtOAc/hexanes) to give the desired compound 15 (21 mg, 11\%). ${ }^{1} \mathrm{H}$ NMR (400 $\left.\mathrm{MHz}, \mathrm{CDCl}_{3}\right) \delta 7.55(\mathrm{~d}, J=1.9 \mathrm{~Hz}, 1 \mathrm{H}), 7.53-7.47(\mathrm{~m}, 2 \mathrm{H})$, 
$7.42(\mathrm{t}, J=7.6 \mathrm{~Hz}, 1 \mathrm{H}), 6.90-6.79(\mathrm{~m}, 3 \mathrm{H}), 4.26(\mathrm{~s}, 4 \mathrm{H})$, $3.75-3.62(\mathrm{~m}, 3 \mathrm{H}), 1.37(\mathrm{~d}, J=6.6 \mathrm{~Hz}, 3 \mathrm{H})$. HR-ESIMS $(\mathrm{m} /$ $z$ ): calcd for $\mathrm{C}_{18} \mathrm{H}_{19} \mathrm{~F}_{3} \mathrm{NO}_{2}(\mathrm{M}+\mathrm{H})^{+}$338.1323; found 338.1363. HPLC purity $=95 \%$ (Method C; $\left.t_{\mathrm{R}}=6.33 \mathrm{~min}\right)$.

1 - (2,3-Dihydrobenzo[b] [1,4]dioxin-6-yl)-N-(3methoxybenzyl)ethan-1-amine (16). Following GP1 with 1(2,3-dihydrobenzo[b][1,4]dioxin-6-yl)ethanamine (100 mg, $0.56 \mathrm{mmol}$ ) and 1-(bromomethyl)-3-methoxybenzene (112 $\mathrm{mg}, 0.56 \mathrm{mmol})$, the resulting product was purified via flash chromatography (0-15\% EtOAc/hexanes) to give compound $16(50 \mathrm{mg}, 30 \%) .{ }^{1} \mathrm{H} \mathrm{NMR}\left(400 \mathrm{MHz}, \mathrm{CDCl}_{3}\right) \delta 7.23(\mathrm{dd}, J=$ 8.6, 7.6 Hz, 1H), 6.92-6.86 (m, 3H), $6.84(\mathrm{~d}, J=1.2 \mathrm{~Hz}, 2 \mathrm{H})$, 6.81-6.76 (m, 1H), $4.25(\mathrm{~s}, 4 \mathrm{H}), 3.81(\mathrm{~s}, 3 \mathrm{H}), 3.73(\mathrm{q}, J=6.6$ $\mathrm{Hz}, 1 \mathrm{H}), 3.69-3.53(\mathrm{~m}, 2 \mathrm{H}), 1.37(\mathrm{~d}, J=6.6 \mathrm{~Hz}, 3 \mathrm{H})$. HRESIMS $(m / z)$ : calcd for $\mathrm{C}_{18} \mathrm{H}_{22} \mathrm{NO}_{3}(\mathrm{M}+\mathrm{H})^{+} 300.1594$; found 300.15912. HPLC purity $=98 \%\left(\right.$ Method $A ; t_{\mathrm{R}}=9.41$ $\min )$.

1 - (2,3-Dihydrobenzo[b][1,4]dioxin-6-yl)-N-(4fluorobenzyl)ethan-1-amine (17). Following GP1 with 1(2,3-dihydrobenzo[b][1,4] dioxin-6-yl)ethanamine $(100 \mathrm{mg}$, $0.56 \mathrm{mmol}$ ) and 1-(bromomethyl)-4-fluorobenzene (105 mg, $0.56 \mathrm{mmol}$ ), the product was purified via flash chromatography (0-15\% EtOAc/hexanes) to give the desired compound 17 (42 mg, 26\%). ${ }^{1} \mathrm{H}$ NMR (400 MHz, $\left.\mathrm{CDCl}_{3}\right) \delta 7.26(\mathrm{td}, J=$ 8.0, $6.0 \mathrm{~Hz}, 1 \mathrm{H}), 7.11-7.01(\mathrm{~m}, 2 \mathrm{H}), 6.97-6.78(\mathrm{~m}, 4 \mathrm{H}), 4.26$ (s, $4 \mathrm{H}), 3.77-3.55(\mathrm{~m}, 3 \mathrm{H}), 1.37(\mathrm{~d}, J=6.6 \mathrm{~Hz}, 3 \mathrm{H})$. HRESIMS $(m / z)$ : calcd for $\mathrm{C}_{17} \mathrm{H}_{19} \mathrm{FNO}_{2}(\mathrm{M}+\mathrm{H})^{+}$288.1394; found 288.1390. HPLC purity $=96 \%\left(\right.$ Method $C ; t_{\mathrm{R}}=6.38$ $\min )$.

$N$-(4-(tert-Butyl)benzyl)-1-(2,3-dihydrobenzo[b][1,4]dioxin-6-yl)ethan-1-amine (18). Following GP1 with 1-(2,3dihydrobenzo[b][1,4] dioxin-6-yl)ethanamine (100 mg, 0.56 $\mathrm{mmol}$ ) and 1-(bromomethyl)-4-(tert-butyl)benzene $(127 \mathrm{mg}$, $0.56 \mathrm{mmol}$ ), the product was purified via flash chromatography (0-15\% EtOAc/hexanes) to give the desired compound 18 (40 mg, 22\%). ${ }^{1} \mathrm{H}$ NMR (400 MHz, $\mathrm{CDCl}_{3}$ ) $\delta 7.37-7.33(\mathrm{~m}$, $2 \mathrm{H}), 7.27-7.22(\mathrm{~m}, 2 \mathrm{H}), 6.92(\mathrm{t}, J=1.2 \mathrm{~Hz}, 1 \mathrm{H}), 6.85(\mathrm{~d}, J=$ $1.1 \mathrm{~Hz}, 2 \mathrm{H}), 4.27(\mathrm{~s}, 4 \mathrm{H}), 3.74(\mathrm{q}, J=6.5 \mathrm{~Hz}, 1 \mathrm{H}), 3.67-3.54$ $(\mathrm{m}, 2 \mathrm{H}), 1.36-1.34(\mathrm{~m}, 3 \mathrm{H}), 1.33(\mathrm{~s}, 9 \mathrm{H})$. HR-ESIMS $(\mathrm{m} / \mathrm{z})$ : calcd for $\mathrm{C}_{21} \mathrm{H}_{28} \mathrm{NO}_{2}(\mathrm{M}+\mathrm{H})^{+}$326.2115; found 326.2108. HPLC purity $=96 \%$ (Method A; $\left.t_{\mathrm{R}}=12.1 \mathrm{~min}\right)$.

7-(3-Fluoro-4-methoxybenzyl)-2,3,6,7,8,9-hexahydro[1,4]dioxino[2,3-g]isoquinoline (19). Following GP1 with 2,3,6,7,8,9-hexahydro-[1,4] dioxino[2,3-g] isoquinoline $(50 \mathrm{mg}$, $0.26 \mathrm{mmol}$ ) and 4-(bromomethyl)-2-fluoro-1-methoxybenzene (69 $\mathrm{mg}, 0.31 \mathrm{mmol}$ ), the product was purified via flash chromatography (0-10\% EtOAc/hexanes) to give the desired compound 19 (52 mg, 60\%). ${ }^{1} \mathrm{H}$ NMR $\left(400 \mathrm{MHz}, \mathrm{CDCl}_{3}\right) \delta$ $7.14(\mathrm{dd}, J=12.2,2.0 \mathrm{~Hz}, 1 \mathrm{H}), 7.07$ (d, $J=8.2 \mathrm{~Hz}, 1 \mathrm{H}), 6.91$ $(\mathrm{td}, J=8.5,1.7 \mathrm{~Hz}, 1 \mathrm{H}), 6.60(\mathrm{~d}, J=1.1 \mathrm{~Hz}, 1 \mathrm{H}), 6.49(\mathrm{t}, J=$ $1.0 \mathrm{~Hz}, 1 \mathrm{H}), 4.21(\mathrm{~d}, J=1.7 \mathrm{~Hz}, 4 \mathrm{H}), 3.88(\mathrm{~d}, J=1.8 \mathrm{~Hz}, 3 \mathrm{H})$, $3.58(\mathrm{~d}, J=1.8 \mathrm{~Hz}, 2 \mathrm{H}), 3.50(\mathrm{~s}, 2 \mathrm{H}), 2.78(\mathrm{t}, J=5.9 \mathrm{~Hz}, 2 \mathrm{H})$, $2.68(\mathrm{t}, J=5.9 \mathrm{~Hz}, 2 \mathrm{H})$. HR-ESIMS $(\mathrm{m} / z)$ : calcd for $\mathrm{C}_{19} \mathrm{H}_{21} \mathrm{FNO}_{3}(\mathrm{M}+\mathrm{H})^{+} 330.15$; found 330.1496 . HPLC purity $=98 \%\left(\right.$ Method $\left.\mathrm{B} ; t_{\mathrm{R}}=4.03 \mathrm{~min}\right)$.

1-((2,3-Dihydrobenzo[b][1,4]dioxin-6-yl)methyl)-5-fluoro$1 \mathrm{H}$-indole (20). Following GP2 with 5-fluoro- $1 \mathrm{H}$-indole $(68$ $\mathrm{mg}, \quad 0.5 \mathrm{mmol})$, the product was purified via flash chromatography (0-15\% EtOAc/hexanes) to give the desired compound $20(100 \mathrm{mg}, 71 \%)$ as a light-yellow oil. ${ }^{1} \mathrm{H}$ NMR $\left(400 \mathrm{MHz}, \mathrm{DMSO}-d_{6}\right) \delta 7.55(\mathrm{~d}, J=3.1 \mathrm{~Hz}, 1 \mathrm{H}), 7.49-7.43$ $(\mathrm{m}, 1 \mathrm{H}), 7.30(\mathrm{dd}, J=9.9,2.5 \mathrm{~Hz}, 1 \mathrm{H}), 6.94(\mathrm{td}, J=9.2,2.6$ $\mathrm{Hz}, 1 \mathrm{H}), 6.79-6.74(\mathrm{~m}, 1 \mathrm{H}), 6.70$ (d, $J=7.0 \mathrm{~Hz}, 2 \mathrm{H}), 6.44$ (dd, $J=3.1,0.9 \mathrm{~Hz}, 1 \mathrm{H}), 5.27$ (s, 2H), 4.17 (s, 4H). HRESIMS $(m / z)$ : calcd for $\mathrm{C}_{17} \mathrm{H}_{15} \mathrm{FNO}_{2}(\mathrm{M}+\mathrm{H})^{+}$284.1081; found 284.1077. HPLC purity $=98 \%\left(\right.$ Method $\mathrm{B} ; t_{\mathrm{R}}=13.06$ $\min )$.

1-((2,3-Dihydrobenzo[b][1,4]dioxin-6-yl)methyl)-5-methoxy-1H-indole (21). Following GP2 with 5-methoxy-1Hindole $(74 \mathrm{mg}, 0.5 \mathrm{mmol})$, the product was purified via flash chromatography (0-15\% EtOAc/hexanes) to give the desired compound $21(112 \mathrm{mg}, 76 \%)$ as a pale white solid. ${ }^{1} \mathrm{H}$ NMR $\left(400 \mathrm{MHz}, \mathrm{DMSO}-d_{6}\right) \delta 7.40(\mathrm{dt}, J=3.0,0.7 \mathrm{~Hz}, 1 \mathrm{H}), 7.31$ (dt, $J=8.9,0.8 \mathrm{~Hz}, 1 \mathrm{H}), 7.02(\mathrm{dd}, J=2.5,0.6 \mathrm{~Hz}, 1 \mathrm{H}), 6.76-$ $6.68(\mathrm{~m}, 2 \mathrm{H}), 6.68-6.61(\mathrm{~m}, 2 \mathrm{H}), 6.33(\mathrm{dd}, J=3.0,0.8 \mathrm{~Hz}$, $1 \mathrm{H}), 5.20(\mathrm{~s}, 2 \mathrm{H}), 4.15(\mathrm{~s}, 4 \mathrm{H}), 3.71(\mathrm{~s}, 3 \mathrm{H})$. HR-ESIMS $(\mathrm{m} /$ $z)$ : calcd for $\mathrm{C}_{18} \mathrm{H}_{18} \mathrm{NO}_{3}(\mathrm{M}+\mathrm{H})^{+}$296.1281; found 296.1278. HPLC purity $=99 \%$ (Method $\left.\mathrm{B} ; t_{\mathrm{R}}=12.53 \mathrm{~min}\right)$.

2-(2,3-Dihydrobenzo[b][1,4]dioxin-6-yl)-6-(3-fluoro-4methoxyphenyl)pyridine (22). A suspension of (2,3dihydrobenzo[b][1,4]dioxin-6-yl)boronic acid (478 mg, 2.66 $\mathrm{mmol}$ ), 2-bromo-6-(3-fluoro-4-methoxyphenyl)pyridine (500 $\mathrm{mg}, 1.77 \mathrm{mmol})$, potassium carbonate $(735 \mathrm{mg}, 5.32 \mathrm{mmol})$, and $\mathrm{Pd}\left(\mathrm{PPh}_{3}\right)_{4}(410 \mathrm{mg}, 0.35 \mathrm{mmol})$ in 1,4-dioxane $(15 \mathrm{~mL}) /$ $\mathrm{H}_{2} \mathrm{O}(2 \mathrm{~mL})$ was irradiated by MWs at $110{ }^{\circ} \mathrm{C}$ for $2 \mathrm{~h}$. The reaction mixture was diluted with EtOAc $(10 \mathrm{~mL})$ and filtered through a short pad of silica. The filtrate was concentrated in vacuo and purified via flash chromatography to give the desired compound (410 mg, 69\%). ${ }^{1} \mathrm{H}$ NMR (400 MHz, $\left.\mathrm{CDCl}_{3}\right) \delta$ $7.96(\mathrm{dd}, J=12.9,2.2 \mathrm{~Hz}, 1 \mathrm{H}), 7.85(\mathrm{ddd}, J=8.5,2.2,1.2 \mathrm{~Hz}$, $1 \mathrm{H}), 7.76-7.69(\mathrm{~m}, 2 \mathrm{H}), 7.65-7.60(\mathrm{~m}, 1 \mathrm{H}), 7.55$ (ddd, $J=$ 7.6, 6.7, 0.9 Hz, 2H), 7.08-6.95 (m, 3H), $4.31(\mathrm{~s}, 4 \mathrm{H}), 3.94(\mathrm{~s}$, $3 \mathrm{H})$. HRMS $(m / z)$ : calcd for $\mathrm{C}_{20} \mathrm{H}_{17} \mathrm{FNO}_{3}(\mathrm{M}+\mathrm{H})^{+}$ 338.1187; found 338.1186. HPLC purity = 94\% (Method D; $\left.t_{\mathrm{R}}=17.92 \mathrm{~min}\right)$.

2-(2,3-Dihydrobenzo[b][1,4]dioxin-6-yl)-6-(3-fluoro-4methoxyphenyl)piperidine (23). 2-(2,3-Dihydrobenzo[b][1,4] dioxin-6-yl)-6-(3-fluoro-4-methoxyphenyl)pyridine 22 $(360 \mathrm{mg}, 1.07 \mathrm{mmol}$ ) and platinum(IV) oxide $(48.5 \mathrm{mg}$, $0.21 \mathrm{mmol})$ were suspended in acetic acid $(5 \mathrm{~mL})$ and degassed with argon. The reaction mixture was kept under hydrogen pressure $(65 \mathrm{psi})$ while shaking for 2 days. The reaction was neutralized with $\mathrm{NaOH}$ to basic $\mathrm{pH}$ and extracted with EtOAc $(3 \times 10 \mathrm{~mL})$. The organic layer was dried over anhydrous $\mathrm{Na}_{2} \mathrm{SO}_{4}$, filtered, and concentrated in vacuo. The crude material was purified via flash chromatography to give the desired compound 23 (21 mg, 6\%). ${ }^{1} \mathrm{H}$ NMR (400 MHz, $\left.\mathrm{CD}_{3} \mathrm{OD}\right) \delta 7.17(\mathrm{dt}, J=12.8,1.8 \mathrm{~Hz}, 1 \mathrm{H}), 7.14-7.09(\mathrm{~m}$, $1 \mathrm{H}), 6.98(\mathrm{t}, J=8.6 \mathrm{~Hz}, 1 \mathrm{H}), 6.90(\mathrm{~d}, J=2.1 \mathrm{~Hz}, 1 \mathrm{H}), 6.83$ $(\mathrm{dd}, J=8.4,2.2 \mathrm{~Hz}, 1 \mathrm{H}), 6.76-6.71(\mathrm{~m}, 1 \mathrm{H}), 4.17(\mathrm{~d}, J=1.6$ $\mathrm{Hz}, 4 \mathrm{H}), 3.82(\mathrm{~d}, J=1.3 \mathrm{~Hz}, 3 \mathrm{H}), 3.74-3.68(\mathrm{~m}, 1 \mathrm{H}), 3.66$ (dd, $J=11.3,2.4 \mathrm{~Hz}, 1 \mathrm{H}), 1.99-1.91(\mathrm{~m}, 1 \mathrm{H}), 1.80-1.43(\mathrm{~m}$, $5 \mathrm{H})$. HR-ESIMS $(\mathrm{m} / z)$ : calcd for $\mathrm{C}_{20} \mathrm{H}_{23} \mathrm{FNO}_{3}(\mathrm{M}+\mathrm{H})^{+}$ 344.1656; found 344.1650. HPLC purity $=92 \%\left(\right.$ Method A; $t_{\mathrm{R}}$ $=10.1 \mathrm{~min})$.

2-(2,3-Dihydrobenzo[b][1,4]dioxin-6-yl)-4-(4methoxyphenyl)thiazole (24). 2-Bromo-1-(4methoxyphenyl)ethanone (117 $\mathrm{mg}, 0.51 \mathrm{mmol}$ ) and 2,3dihydrobenzo $[b][1,4]$ dioxine-6-carbothioamide (100 mg, 0.51 $\mathrm{mmol})$ were suspended in ethanol $(3 \mathrm{~mL})$ and refluxed for $4 \mathrm{~h}$. The reaction mixture was concentrated in vacuo and purified via flash chromatography to give the desired compound 24 (82 $\mathrm{mg}, 49 \%) .{ }^{1} \mathrm{H}$ NMR (400 MHz, $\left.\mathrm{CDCl}_{3}\right) \delta 7.94-7.88(\mathrm{~m}, 2 \mathrm{H})$, $7.58(\mathrm{~d}, J=2.1 \mathrm{~Hz}, 1 \mathrm{H}), 7.53(\mathrm{dd}, J=8.4,2.1 \mathrm{~Hz}, 1 \mathrm{H}), 7.27$ (s, 1H), 6.99-6.94 (m, 2H), $6.93(\mathrm{~d}, J=8.4 \mathrm{~Hz}, 1 \mathrm{H}), 4.31$ (s, $4 \mathrm{H}), 3.86(\mathrm{~s}, 3 \mathrm{H})$. HR-ESIMS $(\mathrm{m} / z)$ : calcd for $\mathrm{C}_{18} \mathrm{H}_{16} \mathrm{NO}_{3} \mathrm{~S}$ 
$(\mathrm{M}+\mathrm{H})^{+}$326.0845; found 326.0841. HPLC purity $=99 \%$

(Method C; $t_{\mathrm{R}}=12.85 \mathrm{~min}$ ).

$N$-(3-Fluoro-4-methoxyphenyl)-2,3-dihydrobenzo[b][1,4]dioxin-6-amine (28). Following GP3 with 2,3-dihydrobenzo[b][1,4]dioxin-6-amine $25(160 \mu \mathrm{L}, 1.3 \mathrm{mmol})$ and 4-bromo2-fluoro-1-methoxybenzene $27(129 \mu \mathrm{L}, 1.0 \mathrm{mmol})$, the product was purified via flash chromatography (0-10\% EtOAc/hexanes) to give the desired compound 28 (124 mg, $45 \%)$ as a pale white solid. ${ }^{1} \mathrm{H}$ NMR $\left(400 \mathrm{MHz}, \mathrm{CD}_{3} \mathrm{OD}\right) \delta$ 6.94-6.87 (m, 1H), 6.73-6.70 (m, 1H), 6.70-6.66 (m, 2H), 6.54-6.47 (m, 2H), 4.22-4.18 (m, 2H), 4.18-4.15 (m, 2H), $3.79(\mathrm{~s}, 3 \mathrm{H})$. HR-ESIMS $(\mathrm{m} / z)$ : calcd for $\mathrm{C}_{15} \mathrm{H}_{15} \mathrm{FNO}_{3}(\mathrm{M}+$ $\mathrm{H})^{+}$276.1030; found 276.1028. HPLC purity $=96 \%$ (Method $\left.\mathrm{E} ; t_{\mathrm{R}}=17.01 \mathrm{~min}\right)$.

$N$-(1-(2,3-Dihydrobenzo[b][1,4]dioxin-6-yl)ethyl)-3-fluoro4-methoxyaniline (29). Following GP3 with 1-(2,3dihydrobenzo[b][1,4] dioxin-6-yl)ethanamine hydrochloride 12 (140 mg, $0.65 \mathrm{mmol}$ ) and 4-bromo-2-fluoro-1-methoxybenzene 27 (103 $\mathrm{mg}, 0.5 \mathrm{mmol}$ ), the product was purified via flash chromatography $(0-10 \% \mathrm{EtOAc} /$ hexanes $)$ to give the desired compound $29(80 \mathrm{mg}, 53 \%)$ as a yellow thick oil. ${ }^{1} \mathrm{H}$ NMR (400 MHz, CD $\left.\mathrm{CD}_{3} \mathrm{OD}\right) \delta 6.81-6.69(\mathrm{~m}, 4 \mathrm{H}), 6.29$ (dd, $J$ $=13.8,2.7 \mathrm{~Hz}, 1 \mathrm{H}), 6.24(\mathrm{ddd}, J=8.8,2.7,1.3 \mathrm{~Hz}, 1 \mathrm{H}), 4.24$ $(\mathrm{q}, J=6.9 \mathrm{~Hz}, 1 \mathrm{H}), 4.18(\mathrm{~d}, J=0.8 \mathrm{~Hz}, 4 \mathrm{H}), 3.70(\mathrm{~s}, 3 \mathrm{H}), 1.39$ $(\mathrm{d}, J=6.7 \mathrm{~Hz}, 3 \mathrm{H})$. ESIMS $(\mathrm{m} / z): 163.08\left(\mathrm{M}-\mathrm{C}_{7} \mathrm{H}_{7} \mathrm{FNO}\right)^{+}$. HPLC purity $=95 \%\left(\right.$ Method $\left.\mathrm{E} ; t_{\mathrm{R}}=16.24 \mathrm{~min}\right)$.

$\mathrm{N}$-(3-Fluoro-4-methoxybenzyl)-2,3-dihydrobenzo[b][1,4]dioxin-6-amine (30). Following GP3 with 6-bromo-2,3dihydrobenzo $[b][1,4]$ dioxine $26(108 \mathrm{mg}, 0.5 \mathrm{mmol})$ and (3-fluoro-4-methoxyphenyl)methanamine 9 (93 mg, 0.65 $\mathrm{mmol})$, the product was purified via flash chromatography (0-15\% EtOAc/hexanes) to give the desired compound 30 (119 mg, 82\%) as a light-yellow oil. ${ }^{1} \mathrm{H}$ NMR (400 MHz, $\left.\mathrm{CD}_{3} \mathrm{OD}\right) \delta 7.10-7.03(\mathrm{~m}, 2 \mathrm{H}), 7.00(\mathrm{t}, J=8.3 \mathrm{~Hz}, 1 \mathrm{H}), 6.57$ $(\mathrm{d}, J=8.6 \mathrm{~Hz}, 1 \mathrm{H}), 6.16(\mathrm{dd}, J=8.6,2.7 \mathrm{~Hz}, 1 \mathrm{H}), 6.12(\mathrm{~d}, J=$ $2.7 \mathrm{~Hz}, 1 \mathrm{H}), 4.16-4.12(\mathrm{~m}, 4 \mathrm{H}), 4.12-4.07(\mathrm{~m}, 2 \mathrm{H}), 3.83(\mathrm{~s}$, $3 \mathrm{H})$. HR-ESIMS $(\mathrm{m} / z)$ : calcd for $\mathrm{C}_{16} \mathrm{H}_{17} \mathrm{FNO}_{3}(\mathrm{M}+\mathrm{H})^{+}$ 290.1187; found 290.1185. HPLC purity $=95 \%\left(\right.$ Method $\mathrm{E} ; t_{\mathrm{R}}$ $=13.14 \mathrm{~min})$.

N-(1-(2,3-Dihydrobenzo[b][1,4]dioxin-6-yl)ethyl)-3-fluoro4-methoxybenzenesulfonamide (33). 1-(2,3-Dihydrobenzo[b][1,4]dioxin-6-yl)ethanamine $12(100 \mathrm{mg}, 0.56 \mathrm{mmol})$ and TEA $(233 \mu \mathrm{L}, 1.67 \mathrm{mmol})$ were dissolved in DCM $(3 \mathrm{~mL})$ and cooled to $0{ }^{\circ} \mathrm{C}$. 3-Fluoro-4-methoxybenzene-1-sulfonyl chloride 31 ( $125 \mathrm{mg}, 0.56 \mathrm{mmol}$ ) was added, and the reaction was stirred at $0{ }^{\circ} \mathrm{C}$ for $3 \mathrm{~h}$. The reaction mixture was then adsorbed onto silica gel and purified via flash chromatography (0-25\% EtOAc/hexanes) to give the desired compound 33 (102 mg, 50\%). ${ }^{1} \mathrm{H}$ NMR (400 MHz, $\mathrm{CDCl}_{3}$ ) $\delta 7.52-7.45(\mathrm{~m}$, $1 \mathrm{H}), 7.32(\mathrm{dt}, J=10.6,2.0 \mathrm{~Hz}, 1 \mathrm{H}), 6.91(\mathrm{td}, J=8.3,1.5 \mathrm{~Hz}$, $1 \mathrm{H}), 6.68(\mathrm{dd}, J=8.2,1.6 \mathrm{~Hz}, 1 \mathrm{H}), 6.58-6.49(\mathrm{~m}, 2 \mathrm{H}), 4.70$ $(\mathrm{d}, J=6.8 \mathrm{~Hz}, 1 \mathrm{H}), 4.42-4.32(\mathrm{~m}, 1 \mathrm{H}), 4.24-4.15(\mathrm{~m}, 4 \mathrm{H})$, $3.93(\mathrm{~d}, J=1.6 \mathrm{~Hz}, 3 \mathrm{H}), 1.41$ (dd, $J=6.9,1.6 \mathrm{~Hz}, 3 \mathrm{H})$. ESIMS $(m / z): 390.08(\mathrm{M}+\mathrm{Na})^{+}$. HPLC purity $=94 \%\left(\right.$ Method $\mathrm{D} ; t_{\mathrm{R}}$ $=15.11 \mathrm{~min})$.

N-(1-(2,3-Dihydrobenzo[b][1,4]dioxin-6-yl)ethyl)-3-fluoro4-methoxybenzamide (34). 3-Fluoro-4-methoxybenzoic acid 32 (95 mg, $0.56 \mathrm{mmol}), 1-(2,3$-dihydrobenzo[b][1,4]dioxin-6yl)ethanamine (100 mg, $0.56 \mathrm{mmol}) 12$, HATU (212 mg, 0.56 mmol), and $N, N$-diisopropylethylamine (DIPEA; $195 \mu \mathrm{L}, 1.12$ $\mathrm{mmol})$ were dissolved in DMF $(3 \mathrm{~mL})$ and stirred at room temperature overnight. The reaction was diluted with water $(10 \mathrm{~mL})$ and extracted with EtOAc $(2 \times 5 \mathrm{~mL})$. The combined organic layer was dried over anhydrous $\mathrm{Na}_{2} \mathrm{SO}_{4}$, filtered, and concentrated in vacuo. The product was purified via flash chromatography (0-35\% EtOAc/hexanes) to give the desired compound 34 (36 mg, 19\%). ${ }^{1} \mathrm{H}$ NMR (400 MHz, $\left.\mathrm{CDCl}_{3}\right) \delta 7.52(\mathrm{q}, J=2.1 \mathrm{~Hz}, 1 \mathrm{H}), 7.50(\mathrm{~d}, J=1.8 \mathrm{~Hz}, 1 \mathrm{H})$, $6.95(\mathrm{t}, J=8.3 \mathrm{~Hz}, 1 \mathrm{H}), 6.88(\mathrm{dd}, J=1.7,0.8 \mathrm{~Hz}, 1 \mathrm{H}), 6.87-$ $6.82(\mathrm{~m}, 2 \mathrm{H}), 6.14(\mathrm{~d}, J=7.6 \mathrm{~Hz}, 1 \mathrm{H}), 5.19(\mathrm{p}, J=7.0 \mathrm{~Hz}$, $1 \mathrm{H}), 4.25$ (s, 4H), $3.92(\mathrm{~s}, 3 \mathrm{H}), 1.55$ (d, $J=6.9 \mathrm{~Hz}, 3 \mathrm{H})$. HRESIMS $(m / z)$ : calcd for $\mathrm{C}_{18} \mathrm{H}_{19} \mathrm{FNO}_{4}(\mathrm{M}+\mathrm{H})^{+}$332.1293; found 332.1292. HPLC purity $=98 \%\left(\right.$ Method $\mathrm{D} ; t_{\mathrm{R}}=12.91$ $\min )$.

$N$-(1-(2,3-Dihydrobenzo[b][1,4]dioxin-6-yl)ethyl)-1-(3-fluoro-4-methoxyphenyl)cyclopropan-1-amine (37). EtMgBr $(1.47 \mathrm{~mL}, 4.4 \mathrm{mmol})$ was added at $-70{ }^{\circ} \mathrm{C}$ to a solution of 3-fluoro-4-methoxybenzonitrile $(302 \mathrm{mg}, 2.0 \mathrm{mmol})$ and tetraisopropoxytitanium $(651 \mu \mathrm{L}, 2.2 \mathrm{mmol})$ in $\mathrm{Et}_{2} \mathrm{O}$ (10 $\mathrm{mL})$ similar to a reported procedure. ${ }^{23}$ The yellow solution was stirred for $10 \mathrm{~min}$. After the solution was warmed to room temperature for $1 \mathrm{~h}, \mathrm{BF}_{3} \cdot \mathrm{Et}_{2} \mathrm{O}(507 \mu \mathrm{L}, 4.0 \mathrm{mmol})$ was added to the dark brown solution. The mixture was stirred for an additional hour; $1 \mathrm{~N} \mathrm{HCl}(6 \mathrm{~mL})$ and EtOAc $(30 \mathrm{~mL})$ were added followed by $\mathrm{NaOH}(10 \%$ aqueous solution, $20 \mathrm{~mL})$. The reaction mixture was extracted with EtOAc $(3 \times 30 \mathrm{~mL})$. The combined organic layers were dried, filtered, and concentrated in vacuo. The product was purified via flash chromatography (0-50\% EtOAc/hexanes) to give intermediate 1-(3-fluoro-4-methoxyphenyl)cyclopropan-1-amine 36 (92 $\mathrm{mg}, 25 \%)$ as a yellow oil. ${ }^{1} \mathrm{H}$ NMR $\left(400 \mathrm{MHz} \mathrm{CDCl}_{3}\right) \delta$ $7.08-6.97(\mathrm{~m}, 2 \mathrm{H}), 6.89(\mathrm{t}, J=8.7 \mathrm{~Hz}, 1 \mathrm{H}), 3.87(\mathrm{~s}, J=0.6$ $\mathrm{Hz}, 3 \mathrm{H}), 1.84(\mathrm{~s}, 2 \mathrm{H}), 1.06-1.01(\mathrm{~m}, 2 \mathrm{H}), 0.94-0.89(\mathrm{~m}$, $2 \mathrm{H})$. ESIMS $(m / z): 182(\mathrm{M}+\mathrm{H})^{+}$. Following GP4 with 1(2,3-dihydrobenzo $[b][1,4]$ dioxin-6-yl)ethanone 35 (50 mg, $0.3 \mathrm{mmol}), 1$-(3-fluoro-4-methoxyphenyl)cyclopropanamine $36(0.05 \mathrm{~g}, 0.28 \mathrm{mmol})$, and $p$-toluenesulfonic acid monohydrate $(5.2 \mathrm{mg}, 0.03 \mathrm{mmol})$, the resulting imine was dissolved in $\mathrm{MeOH}(2 \mathrm{~mL})$ and cooled to $0{ }^{\circ} \mathrm{C} . \mathrm{NaBH}_{4}(30$ $\mathrm{mg}, 0.8 \mathrm{mmol}$ ) was added, and the reaction was stirred overnight upon warming to room temperature. The reaction solution was cooled again to $0{ }^{\circ} \mathrm{C} ; 6 \mathrm{M}$ aq. $\mathrm{HCl}$ was added, and the cooling bath was removed after $30 \mathrm{~min}$. After stirring for $1 \mathrm{~h}$ at room temperature, the reaction mixture was basified with $10 \%$ aq. $\mathrm{NaOH}$ and extracted with $\mathrm{DCM}(3 \times 10 \mathrm{~mL})$; the combined organic phases were washed with brine and dried over anhydrous $\mathrm{Na}_{2} \mathrm{SO}_{4}$. The solvent was removed in vacuo and purified via flash chromatography (0-20\% EtOAc/ hexanes) to give the desired compound $37(11 \mathrm{mg}, 12 \%)$ as a light yellow oil. ${ }^{1} \mathrm{H} \mathrm{NMR}\left(400 \mathrm{MHz}, \mathrm{CDCl}_{3}\right) \delta 7.06-6.97(\mathrm{~m}$, $2 \mathrm{H}), 6.89(\mathrm{t}, J=8.5 \mathrm{~Hz}, 1 \mathrm{H}), 6.78-6.73(\mathrm{~m}, 2 \mathrm{H}), 6.71-6.66$ $(\mathrm{m}, 1 \mathrm{H}), 4.24(\mathrm{~s}, 4 \mathrm{H}), 3.89(\mathrm{~s}, 3 \mathrm{H}), 3.58(\mathrm{q}, J=6.5 \mathrm{~Hz}, 1 \mathrm{H})$, $1.21(\mathrm{~d}, J=6.5 \mathrm{~Hz}, 3 \mathrm{H}), 0.94$ (ddd, $J=9.8,6.5,4.1 \mathrm{~Hz}, 1 \mathrm{H})$, 0.80 (ddd, $J=9.6,6.2,4.2 \mathrm{~Hz}, 1 \mathrm{H}), 0.72(\mathrm{ddd} J=9.9,6.2,4.4$ $\mathrm{Hz}, 1 \mathrm{H}), 0.69(\mathrm{~s}, 1 \mathrm{H})$. HR-ESIMS $(\mathrm{m} / z)$ : calcd for $\mathrm{C}_{20} \mathrm{H}_{23} \mathrm{FNO}_{3}(\mathrm{M}+\mathrm{H})^{+}$344.1656; found 344.1651. HPLC purity $=96 \%$ (Method $\mathrm{E} ; t_{\mathrm{R}}=9.12 \mathrm{~min}$ ).

2-(2,3-Dihydrobenzo[b][1,4]dioxin-6-yl)-N-(3-fluoro-4methoxybenzyl)propan-2-amine (39). To a solution of 1(2,3-dihydrobenzo[ $b][1,4]$ dioxin-6-yl)ethanone 31 (1 g, 5.6 $\mathrm{mmol})$ in dry THF $(10 \mathrm{~mL})$ at $-78{ }^{\circ} \mathrm{C}$ was added a solution of $3 \mathrm{M}$ methylmagnesium bromide $(2.81 \mathrm{~mL}, 8.4 \mathrm{mmol})$. The mixture was stirred for $30 \mathrm{~min}$ and then continually stirred at room temperature overnight. The cloudy yellow reaction mixture was quenched with saturated $\mathrm{NH}_{4} \mathrm{Cl}$ and diluted with EtOAc $(12 \mathrm{~mL})$ and brine $(12 \mathrm{~mL})$. The organic layer was 
washed with water, dried over $\mathrm{Na}_{2} \mathrm{SO}_{4}$, and concentrated in vacuo. The product was purified via flash chromatography (0$10 \% \mathrm{EtOAc} /$ hexanes) to give the tertiary alcohol intermediate (922 mg, 85\%) as a clear oil. ${ }^{1} \mathrm{H}$ NMR $\left(400 \mathrm{MHz}^{\mathrm{CDCl}}{ }_{3}\right) \delta$ $7.01(\mathrm{dd}, J=2.3,0.3 \mathrm{~Hz}, 1 \mathrm{H}), 6.95(\mathrm{dd}, J=8.4,2.3 \mathrm{~Hz}, 1 \mathrm{H})$, $6.83(\mathrm{dd}, J=8.4,0.3 \mathrm{~Hz}, 1 \mathrm{H}), 4.25(\mathrm{q}, J=0.6 \mathrm{~Hz}, 4 \mathrm{H}), 1.66$ $(\mathrm{s}, 1 \mathrm{H}), 1.55(\mathrm{~s}, 6 \mathrm{H})$. ESIMS $(\mathrm{m} / z): 177(\mathrm{M}-\mathrm{OH})^{+}$. To a solution of the alcohol intermediate $(300 \mathrm{mg}, 1.54 \mathrm{mmol})$ in DCM $(10 \mathrm{~mL})$ was added $\mathrm{NaN}_{3}(319 \mathrm{mg}, 4.91 \mathrm{mmol})$ at room temperature under argon. The reaction mixture was cooled to $0{ }^{\circ} \mathrm{C}$, and a solution of TFA $(324 \mu \mathrm{L}, 4.2 \mathrm{mmol})$ in DCM $(1 \mathrm{~mL})$ was added. The reaction was warmed to room temperature and stirred overnight. The white precipitate formed was filtered off, and the filtrate was concentrated in vacuo. The product was purified via flash chromatography (0$5 \% \mathrm{EtOAc} /$ hexanes) to give the tertiary azide intermediate (165 mg, 49\%) as a clear oil. ${ }^{1} \mathrm{H} \mathrm{NMR}\left(400 \mathrm{MHz}, \mathrm{CDCl}_{3}\right) \delta$ 6.97-6.94 (m, 1H), $6.91(\mathrm{dd}, J=8.5,2.3 \mathrm{~Hz}, 1 \mathrm{H}), 6.86-6.83$ $(\mathrm{m}, 1 \mathrm{H}), 4.26(\mathrm{~s}, 4 \mathrm{H}), 1.59(\mathrm{~s}, 6 \mathrm{H})$. ESIMS $(\mathrm{m} / \mathrm{z}): 192(\mathrm{M}-$ $\left.\mathrm{N}_{2}\right)^{+}$. To a hydrogenation bottle was added azide intermediate (160 mg, $0.73 \mathrm{mmol})$ in $\mathrm{MeOH}(2 \mathrm{~mL})$. Under an argon atmosphere, $10 \mathrm{~mol} \% \mathrm{Pd} / \mathrm{C}(39 \mathrm{mg}, 0.05 \mathrm{mmol}$ ) was quickly added to the hydrogenation bottle; it was then capped and placed on the hydrogenator. The reaction was ran at 45 psi overnight, then filtered through Celite, rinsed well with $\mathrm{MeOH}$, and concentrated in vacuo to give the desired tertiary amine compound 38 (133 mg, 94\%) as a clear oil. ${ }^{1} \mathrm{H}$ NMR $\left(400 \mathrm{MHz}, \mathrm{CDCl}_{3}\right) \delta 7.01(\mathrm{~d}, J=2.3 \mathrm{~Hz}, 1 \mathrm{H}), 6.97(\mathrm{dd}, J=$ 8.4, $2.3 \mathrm{~Hz}, 1 \mathrm{H}), 6.82$ (d, $J=8.4 \mathrm{~Hz}, 1 \mathrm{H}), 4.25(\mathrm{q}, J=0.7 \mathrm{~Hz}$, $4 \mathrm{H}), 1.65-1.61(\mathrm{~m}, 2 \mathrm{H}), 1.45(\mathrm{~s}, 6 \mathrm{H})$. ESIMS $(\mathrm{m} / z): 177(\mathrm{M}$ - $\left.\mathrm{NH}_{2}\right)^{+}$. Following GP1 with 2-(2,3-dihydrobenzo[b][1,4]dioxin-6-yl)propan-2-amine $38(58.0 \mathrm{mg}, 0.3 \mathrm{mmol})$ and 3fluoro-4-methoxybenzyl bromide $(65.7 \mathrm{mg}, 0.300 \mathrm{mmol})$, the product was purified via flash chromatography (0-10\% EtOAc/hexanes) to give the desired compound $39(56 \mathrm{mg}$, $56 \%)$ as a clear oil. ${ }^{1} \mathrm{H}$ NMR $\left(400 \mathrm{MHz}, \mathrm{CDCl}_{3}\right) \delta 7.07(\mathrm{dd}, J$ $=12.3,2.1 \mathrm{~Hz}, 1 \mathrm{H}), 7.02-6.95(\mathrm{~m}, 3 \mathrm{H}), 6.90-6.82(\mathrm{~m}, 2 \mathrm{H})$, $4.27(\mathrm{q}, J=0.7 \mathrm{~Hz}, 4 \mathrm{H}), 3.86(\mathrm{~s}, 3 \mathrm{H}), 3.41(\mathrm{~d}, J=0.7 \mathrm{~Hz}, 2 \mathrm{H})$, $1.46(\mathrm{~s}, 6 \mathrm{H}), 1.43(\mathrm{~s}, 1 \mathrm{H}) \cdot{ }^{13} \mathrm{C} \mathrm{NMR}\left(100 \mathrm{MHz} \mathrm{CDCl}_{3}\right) \delta$ $153.51,151.07,146.23,143.07,141.84,141.16,134.68,134.62$, 123.54, 123.51, 118.85, 116.83, 115.99, 115.81, 114.98, 113.24, 113.22, 64.42, 64.37, 56.36, 56.34, 55.63, 46.64, 46.62, 29.73. HR-ESIMS $(m / z): 177.09\left(\mathrm{M}-\mathrm{C}_{8} \mathrm{H}_{9} \mathrm{FNO}\right)^{+}$. HPLC purity $=$ 97\% (Method A; $\left.t_{\mathrm{R}}=9.81 \mathrm{~min}\right)$.

$N$-(2-(2,3-Dihydrobenzo[b][1,4]dioxin-6-yl)propan-2-yl)-3fluoro-4-methoxyaniline (40). Following GP3 with 2-(2,3dihydrobenzo $[b][1,4]$ dioxin-6-yl)propan-2-amine $38(30 \mathrm{mg}$, $0.15 \mathrm{mmol}$ ) and 4-bromo-2-fluoro-1-methoxybenzene 27 (41 $\mathrm{mg}, \quad 0.2 \mathrm{mmol}$ ), the product was purified via flash chromatography (0-10\% EtOAc/hexanes) to give the desired compound 40 (17 mg, 34\%) as a yellow oil. ${ }^{1} \mathrm{H}$ NMR (400 $\left.\mathrm{MHz}, \mathrm{CDCl}_{3}\right) \delta 7.00-6.93(\mathrm{~m}, 2 \mathrm{H}), 6.81(\mathrm{~d}, J=8.3 \mathrm{~Hz}, 1 \mathrm{H})$, $6.67(\mathrm{dd}, J=9.6,8.7 \mathrm{~Hz}, 1 \mathrm{H}), 6.13(\mathrm{dd}, J=13.7,2.8 \mathrm{~Hz}, 1 \mathrm{H})$, 6.08 (ddd, $J=8.8,2.8,1.3 \mathrm{~Hz}, 1 \mathrm{H}), 4.26(\mathrm{~s}, 4 \mathrm{H}), 3.75(\mathrm{~s}, 3 \mathrm{H})$, 1.55 (s, 6H). HR-ESIMS $(\mathrm{m} / z): 177.09\left(\mathrm{M}-\mathrm{C}_{7} \mathrm{H}_{7} \mathrm{FNO}\right)^{+}$. HPLC purity $=95 \%$ (Method A; $\left.t_{\mathrm{R}}=9.53 \mathrm{~min}\right)$.

HTS CPE Assay. Vero E6 cells were obtained from the laboratory of Prof. Ralph Baric, Ph.D., at the University of North Carolina, USA. The Vero E6 cells were grown in MEM/ $10 \% \mathrm{HI}$ fetal bovine serum (FBS)/1\% Pen/Step supplemented with $0.5 \mu \mathrm{g} / \mathrm{mL}$ amphotericin B and harvested in MEM/1\% PSG/1\% HEPES supplemented with 5\% HI FBS. Host cells were mixed with VEEV (TC-83) at an MOI of $\sim 0.001$, allowing for multiple rounds of infection, which resulted in 5$10 \%$ cell viability $72 \mathrm{~h}$ postinfection. A $25 \mu \mathrm{L}$ aliquot of infected cells $\left(1.2 \times 10^{5}\right.$ cells $\left./ \mathrm{mL}\right)$ was added to each well of the assay plates (384 well Corning 3712BC) predrugged with test compounds in media ( $5 \mu \mathrm{L}$ of $6 \times$ the test concentration; the final test concentrations screened were $5 \mu \mathrm{g} / \mathrm{mL}, 10 \mu \mathrm{M}$, or $10 \mu \mathrm{g} / \mathrm{mL}$ depending on the library source). A $25 \mu \mathrm{L}$ aliquot of uninfected cells was added to columns 1 and 2 of each plate for the no virus cell controls $(100 \%$ inhibition of $\mathrm{CPE})$. After incubating plates at $37{ }^{\circ} \mathrm{C} / 5 \% \mathrm{CO}_{2}$ and $90 \%$ humidity for $72 \mathrm{~h}, 30 \mu \mathrm{L}$ of Cell Titer-Glo (Promega) is added to each well. Luminescence was read using a PerkinElmer Envision reader following incubation at room temperature for $10 \mathrm{~min}$ to measure cell viability. The average $Z^{\prime}$ value calculated from 32 positive and negative controls on each of the 672 assay plates run in the HTS was 0.8 . Hit compounds were retested at 10 concentrations in serial 2 -fold dilutions ranging from 40 to $0.8 \mu \mathrm{M}$ (final assay concentration), and $\mathrm{EC}_{50}$ values were calculated by nonlinear regression fit of the data using a 4 parameter Levenberg-Marquardt algorithm (IDBS XLfit model 205) with the minimum and maximum parameters set at 0 and 100, respectively.

HTS Cell Viability Assay. Host cells in media are added in $25 \mu \mathrm{L}$ aliquots (4000-6000 cells/well) to each well of the assay plates (Corning 3712BC) predrugged with test compounds ( $5 \mu \mathrm{L}$ of $6 \times$ the test concentration in media). Cells only ( $100 \%$ viability) and cells treated with hyamine at $100 \mu \mathrm{M}$ final concentration ( $0 \%$ viability) served as the negative and positive controls, respectively, for cytotoxic effect in the assay. DMSO was maintained at $0.3 \%$ for all wells. After incubating plates at $37^{\circ} \mathrm{C} / 5 \% \mathrm{CO}_{2}$ and $90 \%$ humidity for $72 \mathrm{~h}$, $30 \mu \mathrm{L}$ of Cell Titer-Glo (Promega) was added to each well. Luminescence was read using a PerkinElmer Envision reader following incubation at room temperature for $10 \mathrm{~min}$ to measure cell viability. Compounds were tested at 10 concentrations in serial 2-fold dilutions ranging from 40 to $0.8 \mu \mathrm{M}$ (final assay concentration), and $\mathrm{CC}_{50}$ values were determined by nonlinear regression fit of the data using a 4 parameter Levenberg-Marquardt algorithm (IDBS XLfit model 205) with the minimum and maximum parameters set at 0 and 100 , respectively.

Virus Strains and Cells. Venezuelan equine encephalitis virus TC83 $\left(\operatorname{VEEV}_{\mathrm{TC} 83}\right)$ was obtained from Dr. Michael Diamond (Washington University, St. Louis, MO). Mayaro virus $_{\text {TRVL15537 }}\left(\mathrm{MAYV}_{\mathrm{TRVL}}\right)$, Ross River virus (RRV), and O'nyong nyong virus (ONNV) were obtained from Dr. Robert Tesh (University of Texas Medical Branch-Galveston, TX). $\mathrm{CHIKV}_{181 / 25}$ was obtained from Dr. Terence S. Dermody (University of Pittsburgh, Pittsburgh, PA). All alphavirus stocks were propagated on $\mathrm{C} 6 / 36$ cells by infecting with a low multiplicity of infection. At $72 \mathrm{hpi}$, virus was isolated by pelleting through a $20 \%$ sucrose cushion via ultracentrifugation (25 000 rpm, $76618 g, 1.5$ h, Beckman SW32Ti rotor). Titers of viral stocks were determined by serial dilution plaque titration assays on confluent monolayers of Vero cells using a carboxy-methylcellulose overlay. At $48 \mathrm{hpi}$, cells were fixed with $3.7 \%$ formaldehyde containing $1 \times$ phosphate buffered saline and stained with methylene blue dye. Plaques were counted using a dissecting microscope to determine the virus titers.

Vero cells (ATCC CCL-81) and NHDF cells (ATCC PCS201-012) were cultured in Dulbecco's modified Eagle's medium (DMEM) containing $5 \%$ or $10 \%$ fetal bovine serum 
(FBS; ThermoScientific), respectively, and supplemented with $1 \times$ penicillin-streptomycin-glutamine (PSG; Life Technologies) at $37{ }^{\circ} \mathrm{C}$ in $5 \% \mathrm{CO}_{2}$. Aedes albopictus mosquito $\mathrm{C} 6 / 36$ cells (ATCC CRL-1660) were cultured in $5 \% \mathrm{CO}_{2}$ at $28^{\circ} \mathrm{C}$ in DMEM containing 10\% FBS and $1 \times$ PSG.

Cytotoxicity Assay. Compound cytotoxicity was measured at concentrations ranging from 100 to $0.41 \mu \mathrm{M}$ following the CellTiter-Glo luminescent cell viability assay protocol (Promega). Briefly, starting at a concentration of $100 \mu \mathrm{M}$, compounds were diluted 1:3 in a 96-well plate in 5\% DMEM supplemented with PSG. Diluted compound $(50 \mu \mathrm{L})$ was added to the wells of a 96-well black-walled plate (Corning) seeded with $1 \times 10^{4} \mathrm{NHDF}$ cells/well 1 day prior to the assay. At 24 or $72 \mathrm{~h}$ after compound treatment of cells, $50 \mu \mathrm{L}$ of CellTiter-Glo substrate was added to each well, followed by 2 min on an orbital rocker and a $10 \mathrm{~min}$ incubation. The luminescence of each well was measured using a Synergy HTX microplate reader (Biotek, Winooski, VT). Well luminescence was converted to percent cell viability index by dividing the average luminescence value in the experimental wells by the average value in the control wells containing untreated cells and multiplying by $100 . \mathrm{CC}_{50}$ values were calculated by nonlinear regression analysis with compound concentration in log plotted versus cell viability using Prism v7 by GraphPad Software Inc.

Dose Titration, Time of Addition, and Virus Titration. Compounds were resuspended in 100\% dimethyl sufloxide (DMSO, Sigma) at a concentration of $10 \mathrm{mM}$. To produce a 10-point curve ranging from 100 to $0.19 \mu \mathrm{M}$, compounds were diluted in DMEM supplemented with 5\% FBS and PSG starting at $100 \mu \mathrm{M}$ and then diluted $1: 1$ to generate the remaining dilutions. A no treatment control and DMSO control at a concentration of $5 \mu \mathrm{L} / \mathrm{mL}$ were included. Diluted compounds and controls were added to 48-well plates of confluent NHDFs in quadruplicate, for each concentration, $1 \mathrm{~h}$ prior to infection. Unless otherwise stated, cells were infected with an MOI of $1 \mathrm{PFU} /$ cell for $\mathrm{VEEV}_{\mathrm{TC} 83}$ in at least triplicate wells in the presence of compound. At 2 hpi, infection media were removed and plates were washed one time with PBS. Fresh media containing compound were added to the cells. The time of addition studies were completed by treating and infecting cells at the indicated times. At $24 \mathrm{hpi}, 20 \mu \mathrm{L}$ samples of supernatant were collected into 96-well plates and frozen at $-80{ }^{\circ} \mathrm{C}$ for later use in plaque assays to determine the levels of infectious virus production. For the plaque assay, 10 -fold serial dilutions were made in 96-well plates and $100 \mu \mathrm{L}$ of each dilution was transferred into the wells of confluent monolayers of Vero cells in a 48-well plate. At 2 hpi, cells were overlaid with $250 \mu \mathrm{L}$ of carboxymethylcellulose sodium salt (CMC) made in DMEM supplemented with 5\% FBS and PSG. At 48 hpi, plates were fixed with $3.7 \%$ formalin and stained with $0.4 \%$ methylene blue dye. Plaques were counted, and data were prepared by log transformation of compound concentration values and normalization. $\mathrm{IC}_{90}$ values were calculated using a nonlinear regression equation with Prism v7.

RNA Analysis by Northern Blotting. NHDF cells were pretreated with $10 \mu \mathrm{M}$ compound for $1 \mathrm{~h}$ prior to infection with $\mathrm{VEEV}_{\mathrm{TC} 83}$ at an MOI of $5 \mathrm{PFU} /$ cell. At $2 \mathrm{hpi}$, cells were washed $1 \times$ with PBS and fresh media were added containing compound $(10 \mu \mathrm{M})$. At $12 \mathrm{hpi}$, total RNA was isolated from cells using Trizol reagent (Thermo Fisher Scientific) according to the manufacturer's protocol. Isolated RNA was quantified using a Nanodrop spectrophotometer. A $10 \mu \mathrm{g}$ sample of RNA was separated by gel electrophoresis using a $1 \%$ formaldehyde-agarose gel. RNA was transferred to a $\mathrm{N}^{+}$hybond membrane (Amsersham Biosciences) using the capillary transfer method. After transfer, the RNA was fixed to the membrane via UV-cross-linking. DIG-labeled probes for Northern blots were generated by PCR amplification of a 1 $\mathrm{kb}$ fragment spanning the E2-6k-E1 coding region of VEEV; cDNA from $\mathrm{VEEV}_{\mathrm{TC} 83}$ was amplified using primers flanking the region of interest (forward primer: 5'-CTCACTACACGCACGAGCTCATATC; reverse primer: 5'-CTGAGCTTGAGACTGTTCTGGATTG). The human $\beta$-actin DIGlabeled probe was made from PCR amplification of DNA from $\mathrm{pGEM}$ expressing human $\beta$-actin using human $\beta$-actin specific primers (forward primer: 5'-CGCAGTTATCTACAAACGGTA; reverse primer: 5'-TTTACTCTCAGGTGTGCGA). Probes were hybridized overnight at $68{ }^{\circ} \mathrm{C}$ in hybridization buffer. Blots were washed twice for $5 \mathrm{~min}$ with a low stringency buffer, twice with $1 \times$ SSC containing $0.1 \%$ SDS at room temperature (rt), and twice for $15 \mathrm{~min}$ with $0.1 \times \mathrm{SSC}$ containing $0.1 \%$ SDS at $68{ }^{\circ} \mathrm{C}$ and then blocked for $3 \mathrm{~h}$ in blocking solution (Roche) at rt. Anti-DIG-alkaline phosphatase antibody was applied for $30 \mathrm{~min}$ at room temperature. Blots were washed in buffer containing $0.1 \mathrm{M}$ maleic acid, $0.5 \mathrm{M}$ $\mathrm{NaCl}$, and $0.3 \%$ Tween 20 , followed by equilibration in detection buffer (0.1 M Tris- $\mathrm{HCl}, 0.1 \mathrm{M} \mathrm{NaCl}, \mathrm{pH}$ 9.5). Antibodies were visualized using a CSPD alkaline phosphatase substrate and visualized on CL-XPosure film (Thermo Scientific).

Generation of Replicon Particles and Entry Assay. A virus replicon particle expressing VRP-GFP was generated on the basis of the Trinidad strain of VEEV (VEE 3526). ${ }^{21}$ Briefly, replicon plasmid pVR21, containing the viral nonstructural genes and GFP gene, was linearized with Not I and used as a template for in vitro transcription using the Invitrogen mMESSAGE mMACHINE T7 Transcription Kit (Fisher Scientific) following the manufacturer's protocol. Two helper constructs, which express capsid and glycoproteins from VEEV 3526, were also linearized with Not I and transcribed in vitro. $10 \mu \mathrm{g}$ of RNA from each construct was electroporated into BHK-21 cells. At $48 \mathrm{~h}$ post-transfection, supernatants were collected, clarified at $2000 \mathrm{rpm}$ for $15 \mathrm{~min}$, and then ultracentrifuged at $100000 \mathrm{~g}$ for $12 \mathrm{~h}$ at $4{ }^{\circ} \mathrm{C}$ under a $20 \%$ sucrose cushion. Pellets were resuspended in D-PBS (Corning), aliquoted, and stored at $-80{ }^{\circ} \mathrm{C}$ until further use. VRPs were titered on Vero cells by the immunofluorescence assay and were further confirmed to lack replicative virus as is evident from the absence of CPE after two serial passages on Vero cells. To identify the steps where compound $\mathbf{1}$ interferes with VEEV replication, human embryonic kidney 293T (HEK293T) cells were pretreated with either compound $\mathbf{1}$ or $\mathbf{5}$ at a concentration of 1,5 , and $10 \mu \mathrm{M}$ or $10 \mu \mathrm{M}$ DMSO for $1 \mathrm{~h}$. HEK-293T cells were used for this assay because they are susceptible to VEEV infection and they transfect better than primary human fibroblasts NHDF cells. Cells were then infected with VRP-GFP at an MOI of $1 \mathrm{PFU} /$ cell for $1 \mathrm{~h}$, washed with PBS, and replenished with growth media. At 12 hpi, cells were washed with PBS, fixed with $4 \%$ paraformaldehyde (PFA), and analyzed by flow cytometry for the expression of GFP. To determine if the molecule inhibits virus replication at the postentry step, HEK-293T cells were similarly pretreated with the compound $\mathbf{1}$ or 5 at a concentration of 1,5 , and 10 $\mu \mathrm{M}$ or $10 \mu \mathrm{M}$ DMSO for $1 \mathrm{~h}$ and then in vitro transcribed replicon RNA (VRP-GFP) was transfected into the cells using 
Lipofectamine 3000 (Fisher Scientific). At $24 \mathrm{~h}$ posttransfection, cells were washed with PBS and fixed with $4 \%$ PFA, and GFP expression was analyzed by flow cytometry. Differences in drug efficacy of compound 1 in these studies likely reflect differences in VEEV replication efficiency in this cell type and the MOI utilized for these experiments.

Luciferase Assay. To identify the mechanism of action of compound 1, two reporter viruses were generated in the VEEV TC83 background in which NanoLuc (nLuc; 513 nt; developed by Promega Corporation) was inserted either as an nsP3 fusion (TC83 nsP3-nLuc) or between the capsid and PE2 proteins (TC83-Cap-nLuc). These reporter viruses can identify the translation of the incoming genomic RNA as well as translated full-length progeny genomes and $26 \mathrm{~S}$ dependent structural genes. Vero cells $\left(3 \times 10^{4}\right)$ were plated in 24 -well plates $12 \mathrm{~h}$ prior to treatment with compound 1 or 5 for $1 \mathrm{~h}$ prior to infection with TC83 nsP3-nLuc and TC83-Cap-nLuc at an MOI of $5 \mathrm{PFU} /$ cell. At $12 \mathrm{hpi}$, cells were washed twice with PBS and lysed in passive cell lysis buffer (Promega). 20 $\mu \mathrm{L}$ of cell lysate was mixed with $20 \mu \mathrm{L}$ of Nano-Glo Luciferase Assay reagent (Promega), and the luminescence was measured with a luminometer. The luminescence was normalized to protein concentration as measured by the BCA protein assay (Fisher Scientific).

Western Blotting Analysis of VEEV Proteins. Vero cells were pretreated with either compound $\mathbf{1}$ or 5 at 1,5 , and 10 $\mu \mathrm{M}$ or DMSO $1 \mathrm{~h}$ prior to infection with the TC-83 strain of VEEV at an MOI of $5 \mathrm{PFU} /$ cell. At $12 \mathrm{hpi}$, cells were washed twice with PBS and lysed in RIPA lysis buffer with protease and phosphatase inhibitor cocktail (Roche). The total protein in the cell lysates was quantified using the Pierce BCA protein assay kit (ThermoFisher Scientific). Protein lysates were analyzed by Western blotting as described previously. ${ }^{24}$ Briefly, equal amounts of protein $(50 \mu \mathrm{g})$ from each treatment were separated on the Mini-PROTEAN TGX Precast gels (Bio-Rad Laboratories, Hercules, CA) and transferred to polyvinylidene difluoride (PVDF) membranes. Membranes were blocked with $5 \%$ nonfat dry milk in Tris-buffered saline with $0.1 \%$ Tween- 20 (TBS-T) for $1 \mathrm{~h}$ at room temperature followed by incubation with goat anti-VEEV capsid polyclonal antiserum (BEI resources, Cat No. NR-9403), goat anti-VEEV glycoprotein polyclonal antiserum (BEI resources, Cat No. NR-9404), or mouse antihuman $\beta$-actin antibody (Santa Cruz Biotechnology) in $1 \%$ bovine serum albumin (BSA) overnight at $4{ }^{\circ} \mathrm{C}$. Membranes were then washed three times with TBS-T for 10 min and incubated with IRDye $800 \mathrm{CW}$ Donkey anti-Goat IgG $(\mathrm{H}+\mathrm{L})$ or IRDye $800 \mathrm{CW}$ Donkey anti-Mouse IgG $(\mathrm{H}+\mathrm{L})$ (LI-COR Biosciences). After three more washings, membranes were developed with an Odyssey CLX Imaging system (LICOR Biosciences).

Immunofluorescence Assay. Vero cells on coverslips were pretreated with compound $\mathbf{1}$ or $\mathbf{5}$ or DMSO at $10 \mu \mathrm{M} 1 \mathrm{~h}$ prior to infection with the TC-83 strain of VEEV at an MOI of $5 \mathrm{PFU} /$ cell and stained as described. ${ }^{25}$ At $12 \mathrm{hpi}$, cells were fixed with $4 \%$ paraformaldehyde at room temperature for $2 \mathrm{~h}$. After that, cells were washed $5 \times$ with PBS-glycine $(10 \mathrm{mM})$ and incubated with primary antibody (goat anti-VEEV glycoprotein polyclonal antiserum (BEI resources, Cat No. NR-9404)). After an incubation with primary antibody at 37 ${ }^{\circ} \mathrm{C}$ for $1 \mathrm{~h}$, cells were washed again $5 \times$ with $\mathrm{PBS}-$ glycine and incubated with donkey anti-Goat $\operatorname{IgG}(\mathrm{H}+\mathrm{L})$ conjugated with alexa fluor 594 for $1 \mathrm{~h}$ at $37^{\circ} \mathrm{C}$. The cells were washed again with PBS-glycine and mounted with mounting media containing DAPI.

\section{AUTHOR INFORMATION}

\section{Corresponding Authors}

*Phone: +1-205-581-2542. E-mail: apathak@southernresearch. org (A.K.P.).

*Phone: +1-503-418-2772. E-mail: streblow@ohsu.edu (D.N.S.).

ORCID

Corinne E. Augelli-Szafran: 0000-0002-7676-6120

Ashish K. Pathak: 0000-0003-0143-7979

Author Contributions

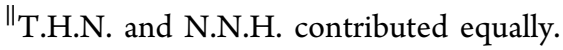

Notes

The authors declare no competing financial interest.

\section{ACKNOWLEDGMENTS}

This work was supported by a grant from the National Institutes of Health (1U19AI109680-01). We also acknowledge Dr. Donghui Bao and Dr. Robert Deimler for their assistance with the ADME evaluation of the compounds. We would like to thank Dr. Ilya Frolov from the University of Alabama at Birmingham for sharing the infectious clone of the TC83 vaccine strain of VEEV.

\section{ABBREVIATIONS}

ADME, absorption, distribution, metabolism, and excretion; $\mathrm{CC}_{50}, 50 \%$ cytotoxic concentration; $\mathrm{CDCl}_{3}$, deuterated chloroform; CHIKV, Chikungunya virus; ${ }^{13} \mathrm{C}$ NMR, carbon13 nuclear magnetic resonance; CYP, cytochrome P450; DCM, dichloromethane; DIPEA, N,N-diisopropylethylamine; DMEM, Dulbecco's modified Eagle's medium; DMF, dimethylformamide; DMSO, dimethyl sulfoxide; $\mathrm{EC}_{90}$, effective concentration for $90 \%$ inhibition of virus; EEEV, Eastern Equine Encephalitis Virus; FBS, fetal bovine serum; FDA, Food and Drug Administration; HATU, 1-[bis(dimethylamino) methylene]-1H1,2,3-triazolo[4,5-b]pyridinium 3-oxide hexafluorophosphate; HLM, human liver microsomes; ${ }^{1} \mathrm{H}$ NMR, proton nuclear magnetic resonance; hpi, hours postinfection; HPLC, high-performance liquid chromatography; HR-ESIMS, high resolution electrospray ionization mass spectra; LAH, lithium aluminum hydride; MAYV, Mayaro virus; MLM, mouse liver microsomes; MOI, multiplicity of infection; NHDF, normal human dermal fibroblast; nsp, nonstructural proteins; ONNV, O'nyong nyong virus; RNA, ribonucleic acid; RRV, Ross River virus; sgmRNA, subgenomic RNA; TEA, triethylamine; THF, tetrahydrofuran; TFA, trifluoroacetic acid; $t_{\mathrm{R}}$ retention time; $p$-TSA, para-toluenesulfonic acid; UNAV, Una virus; VEEV, Venezuelan Equine Encephalitis Virus; VTR, virus titer reduction; WEEV, Western Equine Encephalitis Virus

\section{REFERENCES}

(1) King, A. M. Q., Adams, M. J., Carstens, E. B., and Lefkowitz, E. J. (2012) Family-Togaviridae. In Virus Taxonomy: Ninth Report of the International Committee on Taxonomy of Viruses, pp 1103-1110, Elsevier Academic Press, London, United Kingdom.

(2) Zacks, M. A., and Paessler, S. (2010) Encephalitic alphaviruses. Vet. Microbiol. 140, 281-286.

(3) Aguilar, P. V., Estrada-Franco, J. G., Navarro-Lopez, R. C., Ferro, C., Haddow, A. D., and Weaver, S. C. (2011) Endemic Venezuelan 
equine encephalitis in the Americas: hidden under the dengue umbrella. Future Virol. 6, 721-740.

(4) Rivas, F., Diaz, L. A., Cardenas, V. M., Daza, E., Bruzon, L., Alcala, A., De la Hoz, O., Caceres, F. M., Aristizabal, G., Martinez, J. W., Revelo, D., De la Hoz, F., Boshell, J., Camacho, T., Calderon, L., Olano, V. A., Villarreal, L. I., Roselli, D., Alvarez, G., Ludwig, G., and Tsai, T. (1997) Epidemic Venezuelan equine encephalitis in La Guajira, Colombia, 1995. J. Infect. Dis. 175, 828-832.

(5) Hanson, R. P. (1957) An epizootic of equine encephalomyelitis that occurred in Massachusetts in 1831. Am. J. Trop. Med. Hyg. 6, $858-862$.

(6) Calisher, C. H. (1994) Medically important arboviruses of the United States and Canada. Clin. Microbiol. Rev. 7, 89-116.

(7) Zacks, M. A., and Paessler, S. (2010) Encephalitic alphaviruses. Vet. Microbiol. 140, 281-286.

(8) Morse, S. S., and Zilinskas, R. A. (2011) Alphaviruses, including Venezuelan equine encephalitis virus. In Encyclopedia of Bioterrorism Defense, John Wiley \& Sons, Inc., New York, DOI: 10.1002/ 0471686786.ebd0047.pub2.

(9) Helenius, A., Kartenbeck, J., Simons, K., and Fries, E. (1980) On the entry of Semliki forest virus into BHK-21 cells. J. Cell Biol. 84, 404-420.

(10) Marsh, M., and Helenius, A. (1980) Adsorptive endocytosis of Semliki Forest virus. J. Mol. Biol. 142, 439-454.

(11) Sawicki, D. L., and Sawicki, S. G. (1980) Short-lived minusstrand polymerase for Semliki Forest virus. J. Virol. 34, 108-118.

(12) Lemm, J. A., Rümenapf, T., Strauss, E. G., Strauss, J. H., and Rice, C. M. (1994) Polypeptide requirements for assembly of functional Sindbis virus replication complexes: a model for the temporal regulation of minus- and plus-strand RNA synthesis. EMBO J. 13, 2925-2934.

(13) Nagata, L. P., Wong, J. P., Hu, W., and Wu, J. Q. (2013) Vaccines and Therapeutics for the Encephalitic Alphaviruses. Future Virol. 8, 661-674.

(14) Peng, W., Peltier, D. C., Larsen, M. J., Kirchhoff, P. D., Larsen, S. D., Neubig, R. R., and Miller, D. J. (2009) Identification of thieno $[3,2-b]$ pyrrole derivatives as novel small molecule inhibitors of neurotropic alphaviruses. J. Infect. Dis. 199, 950-7.

(15) Chung, D. H., Jonsson, C. B., Tower, N. A., Chu, Y. K., Sahin, E., Golden, J. E., Noah, J. W., Schroeder, C. E., Sotsky, J. B., Sosa, M. I., Cramer, D. E., McKellip, S. N., Rasmussen, L., White, E. L., Schmaljohn, C. S., Julander, J. G., Smith, J. M., Filone, C. M., Connor, J. H., Sakurai, Y., and Davey, R. A. (2014) Discovery of a novel compound with anti-venezuelan equine encephalitis virus activity that targets the nonstructural protein 2. PLoS Pathog. 10, No. e1004213.

(16) Campos-Gomez, J., Ahmad, F., Rodriguez, E., and Saeed, M. F. (2016) A novel cell-based assay to measure activity of Venezuelan equine encephalitis virus nsP2 protease. Virology 496, 77-89.

(17) Ferreira-Ramos, A. S., Li, C., Eydoux, C., Contreras, J. M., Morice, C., Quérat, G., Gigante, A., Pérez Pérez, M. J., Jung, M. L., Canard, B., Guillemot, J. C., Decroly, E., and Coutard, B. (2019) Approved drugs screening against the nsP1 capping enzyme of Venezuelan equine encephalitis virus using an immuno-based assay. Antiviral Res. 163, 59-69.

(18) https://pubchem.ncbi.nlm.nih.gov/bioassay/588723.

(19) Schroeder, C. E., Yao, T., Sotsky, J., Smith, R. A., Roy, S., Chu, Y.-K., Guo, H., Tower, N. A., Noah, J. W., McKellip, S., Sosa, M., Rasmussen, L., Smith, L. H., White, E. L., Aubé, J., Jonsson, C. B., Chung, D., and Golden, J. E. (2014) Development of (E)-2-((1,4dimethylpiperazin-2-ylidene)amino)-5-nitro- $N$-phenylbenzamide, ML336: Novel 2-amidinophenylbenzamides as potent inhibitors of Venezuelan Equine Encephalitis virus. J. Med. Chem. 57, 8608-8621.

(20) Baell, J. B., and Holloway, G. A. (2010) New substructure filters for removal of Pan Assay Interference Compounds (PAINS) from screening libraries and for their exclusion in bioassays. J. Med. Chem. 53, 2719-2740.

(21) Pushko, P., Parker, M., Ludwig, G. V., Davis, N. L., Johnston, R. E., and Smith, J. F. (1997) Replicon-helper systems from attenuated Venezuelan equine encephalitis virus: expression of heterologous genes in vitro and immunization against heterologous pathogens in vivo. Virology 239, 389-401.

(22) Sun, C., Gardner, C. L., Watson, A. M., Ryman, K. D., and Klimstra, W. B. (2014) Stable, high-level expression of reporter proteins from improved alphavirus expression vectors to track replication and dissemination during encephalitic and arthritogenic disease. J. Virol 88, 2035-2046.

(23) Bertus, P., and Szymoniak, J. (2003) A direct synthesis of 1aryl- and 1-alkenylcyclopropylamines from aryl and alkenyl nitriles. J. Org. Chem. 68, 7133-7136.

(24) Sarkar, S., Bailey, E., Go, Y. Y., Cook, R. F., Kalbfleisch, T., Eberth, J., Chelvarajan, R. L., Shuck, K. M., Artiushin, S., Timoney, P. J., and Balasuriya, U. B. (2016) Allelic variation in CXCL16 determines $\mathrm{CD} 3+\mathrm{T}$ lymphocyte susceptibility to equine erteritis virus infection and establishment of long-term carrier state in the stallion. PLoS Genet. 12, No. e1006467.

(25) Gunn, B. M., Jones, J. E., Shabman, R. S., Whitmore, A. C., Sarkar, S., Blevins, L. K., Morrison, T. E., and Heise, M. T. (2018) Ross River virus envelope glycans contribute to disease through activation of the host complement system. Virology 515, 250-260. 